\title{
EXChange Trading RULES AND STOCK MARKET LIQUIDITY*
}

\author{
Douglas Cumming \\ Associate Professor and Ontario Research Chair \\ York University - Schulich School of Business \\ 4700 Keele Street \\ Toronto, Ontario M3J 1P3 \\ Canada \\ http://ssrn.com/author $=75390$ \\ douglas.cumming@gmail.com \\ Sofia Johan \\ University of Tilburg \\ AFM Senior Research Fellow \\ Tilburg Law and Economics Centre (TILEC) \\ Postbus 90153 \\ 5000 LE Tilburg \\ The Netherlands \\ http://ssrn.com/author=370203 \\ S.A.Johan@uvt.nl \\ Dan Li \\ York University - Schulich School of Business \\ 4700 Keele Street \\ Toronto, Ontario M3J 1P3 \\ Canada \\ http://www.schulich.yorku.ca/ \\ dli06@schulich.yorku.ca
}

This draft: 21 October 2009

\begin{abstract}
* We are indebted to the Paolo Baffi Research Center and Capital Markets CRC for financial support. We owe thanks to Michael Aitken, Paul Irvine, Elisa Di Marco, Benoit Mario Papillon, Thomas Poeppe, and Frank Sensenbrenner for helpful comments and suggestions, as well as the seminar participants at the Canadian Law and Economics Association Annual Conference (September 2007, September 2009), the SMARTS Conference on Surveillance (February 2008), the Bursa Malaysia (April 2008), the University of Amsterdam (September 2008), Bocconi University (October 2008), York University, the University of British Columbia / University of Calgary National Center for Business Law, the DeGroote-Regulation Services Conference on Microstructure (November 2008), the Australasian Banking and Finance Conference (December 2008), the American Law and Economics Association (May 2009), Finlawmetrics (June 2009), and the Northern Finance Association (September 2009).
\end{abstract}




\title{
EXchange Trading RuleS AND STOCK MARKET LIQUIDITY
}

\begin{abstract}
In this paper, we examine stock exchange trading rules for market manipulation, insider trading, and broker-agency conflict, across countries and over time, in 42 stock exchanges around the world. Some stock exchanges have extremely detailed rules that explicitly prohibit specific manipulative practices, but others use less precise and broadly framed rules. We create new indices for market manipulation, insider trading, and broker-agency conflict based on the specific provisions in the trading rules of each stock exchange. We show that differences in exchange trading rules, over time and across markets, significantly effect liquidity.
\end{abstract}

Keywords: Market Manipulation, Liquidity, Insider Trading, Broker-Agency Conflict, Law and Finance

JEL Codes: G12, G14, G18, K22 


\section{Introduction}

Stock exchanges around the world invest considerable manpower, technological effort, and financial resources to curb market manipulation and promote market efficiency and integrity (Aitken and Siow, 2003; Avgouleas, 2005; Comerton-Forde and Rydge, 2006). It is widely regarded that securities law (La Porta et al., 1998, 2006; Jackson and Roe, 2009) and market microstructure (Harris et al., 2008) play an important role in the development of stock markets around the world. Despite these important developments in the literature, there has been a dearth of attention paid to the differences across exchanges with respect to the treatment of market manipulation within their trading rules.

In this paper, we document international differences in trading rules for stock or equity exchanges, and examine the impact of market integrity rules on the performance of equity marketplaces. Specifically, we study the differences in regulation across 42 exchanges worldwide during the time period of 2006-2008 and then proceed to investigate whether integrity-related exchange trading rules matter for market liquidity. For the purposes of this paper "trading rules" refer to the rules and regulations that regulate the activities within a stock market and the conduct of its participants, namely the exchange and the members of the stock exchange who agree to be bound by such rules and regulations.

We create new indices for trading rules pertaining to market manipulation, insider trading, and broker-agency conflict for these 42 stock exchanges in both developed and emerging markets. For the purposes of this paper, market manipulation refers to the trading practices that distort prices and enable manipulators to profit at the expense of other market participants. Insider trading refers to acting on material non-public information. Broker-agency conflict refers to the actions that brokers might take while acting as the agent of a client that benefits the broker (or some other affiliated party) at the expense of the client or the market more generally. Some stock markets such as NASDAQ have extremely detailed rules that explicitly prohibit specific manipulative practices and broker-agency conflict, as well as rules that are designed to curtail the presence of insider trading. For example, NASDAQ's rules provide detailed provisions regarding wash trades, pre-arranged trading, fictitious orders, giving-up priority, churning, front-running, and a variety of other types of practices (all of which are defined herein) that constitute market manipulation. Other exchanges are less precise and have broadly framed rules regarding what constitutes market manipulation and/or broker- agency conflict. 
In view of the significant differences in the way trading rules regulate market manipulation, insider trading, and broker-agency conflict across countries and over time, it is worth considering whether these differences matter. To this end, in addition to documenting the differences in trading rules and developing new indices of market surveillance, we examine whether the differences in trading rules can help to explain the differences in liquidity among exchanges. Specifically, we examine whether there is a correlation between trading rules and a series of liquidity measures that include velocity, volatility, and relative bid-ask spread. The primary function of a marketplace is to provide liquidity to market participants. The effectiveness of an exchange is affected by its rules that regulate security transactions. We consider two competing hypotheses regarding the impact of trading rules on liquidity. On one hand, one can argue that vague regulations create inefficiency as investors and/or traders are not clear as to which activities are acceptable and which ones are in breach of the rules. Detailed rules, therefore, might give rise to greater investor confidence, greater dissemination of knowledge about prohibited conduct, and facilitate invigilation of such rules, which in turn might reinforce investor confidence in the marketplace. As a result, these rules might help to improve trading activity, reduce uncertainty, and decrease trading cost. Conversely, one might argue that detailed regulations create inefficiency as investors and/or traders are able to take advantage of inevitable loopholes, and if so, more detailed exchange rules might have a negative effect on liquidity.

Although exchanges do not amend their rules very frequently, there are nevertheless amendments to rules over time. Most notably for European exchanges, in November 2007 the Directive on Markets in Financial Instruments (MiFID) became effective and thereby gave rise to more detailed rules and more transparent investor protection for the European exchanges. Although some European exchanges, such as the London Stock Exchange, already had in place trading rules that were analogous to the new rules in MiFID, others such as the Austrian exchange had significantly less detailed rules prior to MiFID. Because the introduction of MiFID only effects the countries of the European union, it creates a natural experimental setting in which to assess the impact of exchange rule restrictions on trading activity. In this paper, we exploit this setting to shed light on our research question by examining the dynamics of the market liquidity measures between the two groups of exchanges around the introduction of MiFID. Because MiFID is introduced as a major part of the European Union's Financial Services Action Plan (FSAP) rather than as a result of one single jurisdiction's need to improve the regulation, 
endogeneity issues that relate rule changes to market outcomes are minimized in our experimental setting.

The data presented in this paper show a strong and robust effect of trading rules on liquidity. Detailed trading rules are positively associated with velocity and negatively associated with volatility and bid-ask spreads. We show this effect with panel data that varies across time and countries by considering a variety of robustness checks that include, but are not limited to, fixed-effects modeling and difference-in-differences tests. To isolate the influence of the trading rules, we also control for a number of plausible factors that might effect trading activity based on prior academic works, including exchange institutional features (Röell, 1992), market microstructure aspects (Stoll, 2000) and international differences in securities regulation (La Porta et al., 2006; Jackson and Roe, 2009) among other things. The effect of rules on liquidity is robust to controls for economic, legal, and institutional differences across exchanges that might have been correlated with country differences in drafting trading rules. This strong evidence is due to the fact that exchanges that specifically recognize and prohibit certain acts in the marketplace enhance investor confidence. As well, exchanges with more specific rules invariably have residual "catch-all" clauses that explicitly outline the spirit of the rules and regulations and prohibit a vaguely defined "any other type of manipulative activity" such that (arguably) there is scant scope for exploiting potential loopholes.

A few recent papers are closely related to our own. La Porta et al. (2006) and Jackson and Roe (2009) show that securities law matters for facilitating stock market development in 49 exchanges around the world. Aitken and Siow (2003) provide a ranking of exchanges based on efficiency and integrity. Cumming and Johan (2008) provide survey evidence that surveillance technology and information sharing facilitate market integrity. Hail and Leuz (2006), Daske et al. (2008) and Lampert et al. (2007) show that stronger securities law, accounting rules, and stricter enforcement mechanisms lower firms' cost of capital. The findings in these papers are consistent with a broader literature on the importance of securities regulation and market surveillance for market efficiency and integrity. ${ }^{1}$ More generally, our paper contributes to the general question of

1 See, e.g., Aggarwal (2001), Aggarwal and Wu (2003), Allen and Gale (1992), Allen and Gorton (1992), Carson (2003), Clayton et al. (2006), Comerton-Forde and Rydge (2006), Comerton-Forde and Tang (2007), Daouk et al. (2006), DeMarzo et al. (2005), Gerard and Nanda (1993), Harris (2006), Harris (2002), Hillion and Suominen (2004), Jarrow (1992, 1994), Kumar and Seppi (1992), La Porta et al. (1997, 1998, 1999, 2002, 2006), Mahoney (1999), Merrick et al. (2005), Ni et al. (2005), Pagano et al. (2001, 2002), Peng and Röell (2009), O’Hara and Mendiola (2003), Pirrong (1993, 1995a,b, 1999, 2004), Pistor et al. (2003), Pistor and Wu (2003, 2005), Prichard (2003), Reiffen and Robe (2007), Romano (1993, 2001, 
the value of broadly framed versus specific rules in regulating markets and society (see, e.g., Ferguson and Peters, 2003; Stevenson, 2005).

In this paper, we provide a novel source of information for understanding the sources of international differences in stock exchanges. We show that stock exchange trading rules, which specify in detail rules that pertain to market manipulation, facilitate trading activity. The implication is that an exchange's trading rules are an important source of international differences in stock markets. This information is very transparent and readily visible for use in future research. An index of exchange trading rules is provided herein.

This paper is organized as follows. Section 2 describes stock exchange trading rules and the creation of an index for exchange surveillance. The data are introduced in Section 3. Section 4 presents multivariate analyses of the relation between the exchange surveillance index and trading activity. Concluding remarks follow in the last section.

\section{The indices of exchange trading rules and hypothesis}

In this section, we explain forms of market manipulation, insider trading, and brokeragency conflict, and build indices for stock exchange trading rules. Rules can be broken down into one of three types: rules designed to mitigate insider trading, rules designed to limit market manipulation, and rules designed to limit broker-agent conflicts. Each are described immediately below.

\subsection{Indices of exchange trading rules}

\subsubsection{Insider trading rules index}

Insider trading refers to a market participant who acts on material non-public information. Although rules prohibiting insider trading in general are commonplace around the world, specific regulations governing market participants with respect to insider trading differ significantly across exchanges.

2002) and Vitale (2000). 
Insider trading can take many different forms, two of which involve brokers using the information of a client order: client precedence and front-running. Client precedence refers to brokers violating the time priority of client orders. A client precedence rule is violated during insider trading when a broker initiates a trade on his own account shortly ahead of the execution of a client's order, with the client's trade being executed at a worse price. Front-running likewise refers to brokers trading ahead of clients' orders. In the case of front-running, upon receipt of a large client order, a broker trades shortly prior to a client's order with the expectation that the client's order will move the price. Front-running can also involve brokers that, after receiving a client's order, take the opposite position to the client's order in the market without the client's knowledge and then, immediately thereafter, the same broker crosses with the same client offmarket at a profit.

Other forms of insider trading can involve the use of material non-public information about the company being traded. Trading rules can mitigate the presence of this form of insider trading by prohibiting trading ahead of the public release of research reports created by brokerages, and the separation of research and trading departments at brokerages (commonly referred to as "Chinese Walls"). As well, rules that limit affiliation between exchange members and member companies, or between members and their investment company securities, mitigate the flow of information that might be material and non-public. Rules can also provide details with respect to the nature of communication between brokerages and the public by regulating how the flow of material non-public information is released. Further, trading rules sometimes limit brokerage ownership, the extent to which brokerages can influence or reward employees of others, or ban anti-intimidation and/or coordination activities (e.g., to stop people from reporting illegal activities). These restrictions can have the effect of limiting the flow of material nonpublic information. ${ }^{2}$

\subsubsection{Market manipulation rules index}

Market manipulation rules encompass price manipulation, volume manipulation, spoofing, and disclosure manipulation.

\footnotetext{
2 In some countries the probability of detection of insider trading is low and even upon deterction and prosecution, the ensuing fines are also low. We considered separate variables for insider trading laws around the world (Beny, 2005), among others, but those variables did not materially impact the results presented here regarding the market manipulation index and trading velocity.
} 


\section{1.2.1. Price manipulation rules index}

Price manipulation can be carried out in many different ways and take many forms. One common way is where one broker (or colluding brokers) enters purchase orders at successively higher prices to create the appearance of active interest in a security, which is also termed as ramping/gouging. This can also take the form of pump and dump schemes whereby exchange participants generate a significant increase in price and volume for a security, carry out a quick flip, and the securities are then sold (often to retail customers) at the higher prices. Another similar type of price manipulation takes the form of pre-arranged trading. Pre-arranged trades involve colluding parties simultaneously entering orders at an identical price and volume. Because pre-arranged trades avoid the order queue, they can influence the price of a security.

Price manipulation can be carried out through domination and control, and take the forms of corners or squeezes in cross-market activity. Corners and squeezes involve shortages in one market that can affect the price of a cross-market security A corner involves securing control of the bid- or demand-side of both the derivative and the underlying asset, and the dominant position can be exploited to manipulate the price of either. A squeeze involves taking advantage of a shortage in an asset by controlling the demand-side and exploiting market congestion during such shortages in a way that creates artificial prices. Another related form of manipulation includes mini-manipulations whereby trading in the underlying security of an option is carried out in order to manipulate its price so that the options will become in-the-money (Merrick et al., 2005).

Price manipulation can also be carried out to take advantage of market setting whereby brokers cross-order at the short-term high or low to effect the volume weighted average price, or to set the price in one market for the purpose of a cross in another market.

Three different forms of price manipulations refer to a specific time period: marking the open with regard to the opening of the market, marking the close with regard the closing of the market, and trades to manipulate prices at end of the month/quarter/year. The opening session can be subject to particular types of manipulation subject to the rules for entering bids and asks in the pre-opening session. Similarly, end-of-day trades may be geared towards manipulating the closing market price of the security, and exchanges often specifically prohibit this type of act. 
Financial record keeping among companies provides incentives to manipulate share prices around the end of the month/quarter/year that depend on the governance specific to the company.

\section{1.2.2. Volume manipulation rules index}

Volume manipulation can take two primary many forms: churning and wash trading. Churning refers to the excessive trading of a stock to inflate its volume thereby giving rise to the false impression that there is investor sentiment for the stock. While we recognize that the churning of client accounts may be carried out by traders and/or brokers to generate commission fees, given that the end result of churning is to manipulate markets, and that the central motivation of traders and/or brokers in churning both house accounts and client accounts is to manipulate the appearance of volume, we have deemed churning as a form of volume manipulation.

Wash trading, another form of volume manipulation, means having the same client reference is on both sides of a trade. While there is no beneficial change in ownership, wash trades have the effect of creating a misleading appearance of an active interest in a stock. We realize that wash trades can indirectly effect price, but we consider wash trades to more significantly affect volume. As such, wash trades are categorized as part of volume manipulation.

\section{1.2.3. Spoofing manipulation rules index}

Spoofing, also known as "painting the tape", is a form of market manipulation that involves actions taken by market participants to give an improper or false impression of unusual activity or price movement in a security. Some trading rules have very general statements of prohibition towards actions that give rise to a false appearance. Other exchanges more explicitly indicate ways in which false appearance might be created, which includes fictitious orders, giving up priority, layering of bids-asks, and switches. The more general act of entering fictitious orders involve entering orders on one side of the market, then completing orders on the other side of the market and deleting the original order after the trade occurs. Giving up priority refers to deleting orders on one side of the market as they approach priority and then entering the order again on the same side of the market. Layering of bids-asks refers to traders or brokers that stagger orders from the same client reference at different price and volume levels to give the misleading impression of greater interest in the security from a more diverse set of exchange participants, and 
might be viewed as being carried out for the purpose of manipulation. Switches involve deleting orders on one side of the market as they approach priority and then entering the order again on the opposite side of the market. These distinctions are somewhat subtle but nevertheless these different scenarios are explained in detail in some exchange trading rules.

\section{1.2.4. False disclosure rules index}

Distinct from insider trading rules, some rulebooks include information pertaining to false disclosure. For instance, market participants might actively distribute false or misleading information that has the effect of distorting the marketplace. Alternatively, there can be a failure to disclose information such as the mandatory disclosure of ownership interests when they reach threshold level. This latter form of manipulation is commonly known as parking or warehousing.

Overall, we refer to trading rules pertaining to price manipulation, volume manipulation, spoofing, and false disclosure as the market manipulation rules. Below, we aggregate these rules to form separate indices for each, which we refer to as subcomponent indices. Then we combine them in their sum total to form the Market Manipulation Rules Index, one of the three primary legal indices we are creating in this paper. These indices are considered separately from insider trading rules and broker-agency conflict rules, which form the other two primary indices.

\section{1.3. Broker-agency conflict rules index}

Brokers act on behalf of clients, but can do so in ways that are against client interests. This type of principal agent problem may arise from the failure of the broker to obtain the best price for a client (commonly known as a breach of a trade through obligation ${ }^{3}$ ), the broker charging excessive fees, or acting in ways that are generally detrimental to client interests such as by investing in securities that do not match the risk/return profile of the client (referred to as breach of the "know-your-client rule"). As well, brokers might use the exchange's name improperly in marketing their services, or carry out other forms of improper or unethical sales and marketing efforts. For broker-agency conflict rules, we use information explicitly indicated in the rules of the exchange, and not guidelines from professional associations such as the Chartered Financial Analysts ethics guidelines and the like.

\footnotetext{
3 In the U.S., this obligation was released under Regulation NMS and published in the federal register in June 2005.
} 
Table 1 outlines the different types of manipulation described in stock exchange trading rules. The trading rules for a stock exchange are drafted with varying degrees of specificity as they outline the exchange membership requirements, listing requirements, trading rules and regulations, and especially trading practices that are prohibited.

\section{[Insert Table 1 About Here]}

Each of the different rules for insider trading, market manipulation, and broker-agency conflict described in the exchanges' trading rules are weighted equally in the indices used in this paper. ${ }^{4}$ The Insider Trading Rules Index comprises ten items. Market Manipulation Rules Index encompasses a total of 14 items, which include price manipulation (seven items), volume manipulation (two items), spoofing (three items), and false disclosure (two items). BrokerAgency Conflict Rules Index comprises five items. However, it is possible that certain rules are relatively more important, but we do not have enough degrees of freedom to treat each rule separately. Plausible adjustments to different weightings do not materially change the empirical results reported below.

The Insider Trading Rules and Market Manipulation Rules Indices also consider securities regulation provisions when they are specific about the regulations pertaining to trading on stock exchanges. Our analyses of securities codes revealed a couple of cases where the trading rules were more detailed in securities law. In China, we use the rules of the China Securities and Regulatory Commission for the Shanghai and Shenzhen exchanges. In Canada, the pertinent rules are found in the Universal Market Integrity Rules, which come from an independent regulatory body known as the Investment Industry Regulatory Commission of Canada. By contrast, the Broker-Agency Conflict Rules Index does not consider professional association rules, such as that of the Chartered Financial Analysts Code of Professional Conduct. The reason for this exclusion is that the exchange members are not obligated to be a part of these different professional associations in order to trade on the exchange.

\subsection{Testable hypotheses}

\footnotetext{
4 The equal weighting is consistent with the approach used in most law and finance studies, such as those by La Porta et al. (1998, 2006).
} 
Following market microstructure literature, we focus on the three major measures of liquidity: velocity, volatility, and bid-ask spread. Trading velocity is defined as the domestic share turnover per domestic market capitalization (World Federation of Exchanges, 2006-2008). High velocity is associated with the high turnover of stock, which means that shares change hands more frequently, implying a more liquid market. On the other hand, following Roll (1988), Massimb and Phelps (1994), and Madhavan et al. (2005), higher volatility implies lower liquidity. Bid-ask spread is the compensation for providing immediacy, which a trader receives for the risks that he might have to unwind his position at a loss in the future. A smaller spread is associated with higher liquidity (Amihud and Mendelson, 1988; Massimb and Phelps, 1994).

Below we test the proposition that explicit rules pertaining to insider trading, market manipulation as well as broker-agency conflict enhance investor confidence, mitigate abuse, and thereby facilitate trading activity. In other words, the central hypothesis considered herein is that vague exchange trading rules do not provide adequate guidance and information for investors and/or traders, who are not sufficiently clear as to which activities are unacceptable, and as such investors and traders are less likely to trade in the market for fear that it is more likely to be manipulated. The competing hypothesis is that detailed regulations give rise to loopholes that investors and traders can take advantage of, thereby creating inefficiencies and lowering trading activity. A priori, our expectation is that the latter effect is outweighed by the former, as detailed regulations can signal to market participants that exchanges actively monitor and enforce regulations pursuant to investor protection (see, generally, Laffont and Tirole, 1993). We therefore expect that detailed trading rules enhance velocity, and reduce stock market volatility and bid-ask spreads.

In addition to differences in levels of rule detail across countries, in our analysis we also make use of a material change to trading rules across countries due to the Directive on Markets in Financial Instruments (MiFID). In November 2007, MiFID, an European-wide harmonization directive, became effective. Because the timing, motivation and content of MiFID was not instigated by any one specific European exchange or European country, but at the European Union level, this legislative change can be regarded as exogenous, thereby providing a useful test of causality between rules and liquidity. We expect that the substantial details provided in MiFID enhanced investor protection and facilitated liquidity. The next sections of the paper test these hypotheses. 


\section{The sample and summary statistics}

\subsection{The sample}

Our sample comprises 42 stock exchanges that are members of the World Federation of Exchanges (2006-2008) and are included in commonly used data sources such as Thomson Reuters Datastream. The sample comprises Argentina, Australia, Austria, Bermuda, Brazil, Canada, China (Shanghai and Shenzhen), Chile, Colombia, Egypt, France, Germany, Greece, Hong Kong, India (Bombay and the National Stock Exchange of India), Indonesia, Ireland, Israel, Italy, Japan, Jordon, Korea, Malaysia, Mexico, New Zealand, Norway, Peru, Philippines, OMX (Sweden, Finland, Denmark), Singapore, Slovenia, Spain, Sri Lanka, Switzerland, Taiwan, Thailand, Turkey, the United Arab Emirates, the U.K., and the U.S. (NASDAQ and NYSE). Trading rules for these stock exchanges are found on the each exchange's webpage, with the sole exception of China, where the pertinent trading rules for the Shanghai and Shenzhen exchange are found on the China Securities and Regulatory Commission webpage.

The definitions of the variables used in the analyses are provided in Table 1. From the World Federation of Exchanges (2006-2008), we use the annualized monthly trading velocity values for February 2006 - October 2008; the period considered by this study. The domestic market capitalization at the end of each month, monthly total value of share trading, and data for the total number of trades for each stock exchange are also obtained from the World Federation of Exchanges. Volatility and bid-ask spreads for each exchange are based on the stocks that comprise the exchange's main index, for all exchanges, from the Thomson Reuters Datastream. Firm volatility is the annualized monthly volatility calculated using the prior 60 months of returns. Volatility of each marketplace is the month-end firm capitalization weighted average of the firm volatilities. Following Chordia et al. (2002), we compute the value-weighted quoted spread for each exchange. The percentage quoted bid-ask spread of each is the difference between the ask and bid price divided by the mid-point of the bid and ask price, ${ }^{5}$ which is then averaged to calculate the spread of the exchange, weighted by firm market capitalization. If the month-end spread is missing due to market close, the nearest prior day with a non-missing spread is used for the calculation.

\footnotetext{
$5 \quad$ The percentage quoted bid-ask spread is winsorized at the $5 \%$ level due to the existence of negative quoted spreads in Datastream (on select days due to timing of reported values). For consistency, volatility and velocity are likewise winsorized at the $5 \%$ level. Our analyses are robust to winsorizing at the $1 \%$ level and robust to not winsorizing.
} 
Following Röell (1992), we define a hybrid exchange-dummy variable to control for the impact of market structure on liquidity. This dummy is set to equal one for exchanges with both floor trading and limit order book, and zero otherwise. The microstructure data listed in Table 1 are collected from various sources including the exchange webpages, directories, and handbooks, as well as the World Federation of Exchanges (2006-2008) and Yahoo Finance.

Surveillance data are used from Cumming and Johan (2008). Cumming and Johan surveyed 25 exchanges around the world to ascertain the extent of single- and cross-market surveillance. The data were obtained confidentially for the period 2004-2005 because a wouldbe manipulator might trade in ways that could not be detected if precise information about surveillance activity was available. ${ }^{6}$ The data are based on an equally weighted index that adds one every time a different type of single- and cross-market manipulation is monitored. We use the principal components of domestic- and cross-market surveillance to mitigate collinearity associated with other microstructure and country-specific variables of interest.

We also acquire a series of law and finance indices from La Porta et al. $(1998,2006)$ and Spamann (2009), which include efficiency of the judiciary, anti-director rights, and liability standards. ${ }^{7}$ Other legal indices were considered, but they did not impact the empirical tests reported below and are therefore excluded for conciseness. ${ }^{8}$ To control for the influence of market specific changes, we draw a series MSCI Global Standard Index from Morgan Stanley Capital International's webpage, and add year-dummy variables in our multivariate analyses.

\subsection{Summary statistics}

Table 2 provides summary statistics of the trading rule variables collected for this paper. There are three primary legal indices introduced: the Insider Trading Rules Index, the Market

6 Comparable data for the 2006-2008 time period were not forthcoming from the exchanges in our sample, and as such this surveillance data represent a proxy for the monitoring activity of the 2006-2008 time period in which we have trading rule data and changes over time from MiFID.

7 Where these variables are not defined for a particular country, we use the average value of the legal origin family for that particular country. As a robustness check in the empirical tests provided below, we exclude these countries from the data and find the results do not materially change. Further, our results pertaining to the trading rule indices are invariant to use of the La Porta et al. $(1998,2006)$ indices versus Spamann's (2009) index for anti-director rights and other updates, as well as other variables from Jackson and Roe (2009).

8 See, e.g., supra note 2 and accompanying text. Extra details and empirical tests with additional indices are available upon request. 
Manipulation Rules Index, and the Broker-Agency Conflict Rules Index. The Market Manipulation Rules Index consists of four subcomponents: the Price Manipulation Rules Index, the Volume Manipulation Rules Index, the Spoofing Manipulation Rules Index, and the False Disclosure Rules Index. These indices are summarized in Table 2 for the year 2008. As discussed above in Section 2, the indices are created by summing up the number of specific provisions in the exchange trading rules in each country. The Insider Trading Rules Index varies from a low value of zero (for a number of exchanges listed in Table 2) to ten (for NASDAQ). The Market Manipulation Rules Index varies from a low value of zero (for Chile, Peru, Philippines, and Turkey) to 13 (for London, NYSE, Euronext Paris, and Slovenia). The BrokerAgency Conflict Rules Index varies from a low value of zero (for a number of exchanges listed in Table 2) to five (for NASDAQ).

\section{[Insert Table 2 About Here]}

Table 3 indicates the summary statistics for all of the country-years in the data. The average monthly velocity in the sample is $95.1 \%$, and the median is $70.9 \%$. The range is $11.5 \%$ to $218.3 \%$. One standard deviation in velocity is $63.2 \%$. The average annualized market capitalization weighted volatility is $31.9 \%$, with a range between $21.1 \%$ and $48.5 \%$. The average bid-ask spread is $0.75 \%$, with a minimum of $0.10 \%$ and a max of $7.4 \%$. The number of nonmissing country-month observations for velocity is 1363 due to the coverage by the World Federation of Exchanges. ${ }^{9}$ The number of country-month observations with non-missing volatility data is 1319 and non-missing spread data is 988 due to Datastream coverage. ${ }^{10}$ Table 3 also provides summary statistics for the legal indices and MSCI and GDP per capita.

\section{[Insert Table 3 About Here]}

Table 4 provides a comparison of means and medians tests of volume in relation to different cutoff values, which are the median value of the legal indices. Part 1 of Panel A reports differences in means and medians of velocity for the full sample of all country-years in the data. The data indicate velocity is significantly higher for higher values in the Insider Trading Rules

\footnotetext{
$9 \quad$ Velocity data from the World Federation of Exchanges is available monthly from February 2006 for most countries except Jordan where data start in January 2008.

10 For example, Datastream does not cover the bid and ask price for Argentina, Columbia, Peru, Chile, India (both Bombay and the National Stock Exchange of India), Israel and Bermuda. The bid and ask price data types for the Canadian market begin from November 27, 2006.
} 
Index. The average (median) velocity is $111.9 \%$ (72.2\%) for exchanges with three or more insider trading rules, and is $80.8 \%$ (55.7\%) for exchanges with values of zero or one in the Insider Trading Rules Index. Similar results are observed for differences in the Market Manipulation Rules Index. The average (median) velocity is $113.4 \%$ (63.6\%) for exchanges with five or more market manipulation rules, and is $68.9 \%(54.5 \%)$ for exchanges with four or fewer market manipulation rules. These differences in means and medians are statistically significant at the $1 \%$ level. Likewise, the subcomponents of the Market Manipulation Rules Index show statistically significant differences at the $1 \%$ level for price manipulation, volume manipulation, spoofing, and false disclosure. We compare the results with an Investor Protection Index, which is the principal component of (1) anti-director rights, (2) disclosure requirements, and (3) liability standards (La Porta et al., 2006; see also Spamann, 2009). Unlike the results for our Insider Trading Rules Index and Market Manipulation Indices, there are no significant differences for the Investor Protection Index either in terms of means or medians. Nevertheless, the La Porta et al. (2006) Investor Protection Index does show significant differences at the $1 \%$ level for values of three or more versus values of two or less. This latter result indicates that the trading rules indices in this paper might be correlated with other legal differences across countries, such as the Investor Protection Index, and hence in our empirical assessment of trading rules on trading velocity below we control for other legal and economic differences across countries.

[Insert Table 4 About Here]

Part 2 of Panel A of Table 4 considers differences in the indices for the subset of European exchanges for which MiFID applies. The results are broadly consistent with those reported in Part 1 of Panel A, with a few exceptions. The mean and median values of velocity for the Market Manipulation Rules Index are not significantly different, as are the mean and median values for price. The velocity is significantly lower for exchanges with a higher value in the False Disclosure Rules Index, the opposite of that of the whole sample. Nevertheless, the differences in means and medians for the Broker-Agency Conflict Rules Index and the Investor Protection Index are statistically significant.

Part 3 of Panel C of Table 4 compares velocity for the pre- and post-MiFID time periods (pre-November 2007 and post-November 2007) for both the exchanges affected by MiFID ("MiFID exchanges") and exchanges not affected by MiFID ("non-MiFID exchanges") in the data. The data indicate that for the MiFID exchanges both average and median velocity was 
significantly higher after MiFID (average of $126.7 \%$ and median of 137.3\%) than before MiFID (average of $113.7 \%$ and median of 127.6\%). For the non-MiFID exchanges, both average and median velocities were not statistically different pre- and post-November 2007 (averages were $78.0 \%$ and $82.7 \%$, and medians were $56.3 \%$ and $67.9 \%$, respectively).

Table 4 Panel B Part 1 presents the differences in means and medians of volatility for the full sample and the subsample in which MiFID applies. The results are generally consistent with our hypotheses. Both mean and median tests of the full sample show that market capitalization weighted volatility is significantly lower for exchanges with higher exchange rule indices, except for the Broker-Agency Conflict Rules Index. The tests in Part 2 of Panel B that use MiFID country data support our central hypothesis for the Market Manipulation Rules Index and all of its subcomponent indices, but not the Insider Trading Rules, Broker-Agency Conflict Rules, and Investor Protection Indices. Part 3 of Panel B shows that average and median volatility is smaller after November 2007 for MiFID exchanges and those differences are significant at the $1 \%$ level, and the non-MiFID exchanges observe a slight increase in volatility but this change is insignificant. Again, these findings support our central hypothesis.

Table 4 Panel C provides comparison results for the bid-ask spread. The data indicate that the Insider Trading Rules Index, the Market Manipulation Rules Index, and its subcomponent indices are associated with a smaller bid-ask spread for the full sample in Part 1 of Panel C. In Part 2 of Panel $\mathrm{C}$, the subset of exchanges affected by MiFID provides inconsistent results; only a higher Volume Manipulation Rules Index is associated with a lower bid-ask spread. Part 3 of Panel $\mathrm{C}$ shows the comparison of pre- and post- bid-ask spreads. It indicates that there is no significant change in spread for MiFID exchanges, but there is a significant increase in spreads after November 2007 for non-MiFID exchanges.

Taken together, these statistics show there is a material effect of MiFID on liquidity measures, which is consistent with our hypothesis that MiFID has a positive impact on market liquidity. The evidence of changes in liquidity in the post-MiFID period also indicate the need to assess difference-in-differences tests in the econometric tests. As well, the differences over time suggest a need to control for market factors in assessing the determinants of liquidity.

Table 5 presents a correlation matrix for the main variables used in the multivariate tests provided in the next section. As predicted, there is a strong positive correlation between trading 
velocity and the Insider Trading Rules Index (0.33), the Market Manipulation Rules Index (0.38), its subcomponent indices, as well as the Broker-Agency Conflict Rules Index, all of which are statistically significant at the $1 \%$ level. GDP per capita is likewise highly positively correlated with trading velocity (0.39). Volatility is also highly correlated with trading volume, numbers of trades, and market capitalization. Similarly, volatility and bid-ask spread are negatively significantly correlated with the trading rule indices, which is consistent with our central hypothesis.

[Insert Table 5 About Here]

\section{Multivariate analyses}

In this section, we consider whether MiFID has an impact on market liquidity, and which legal factors are most closely associated with cross-sectional differences in liquidity, while controlling for other economic and institutional determinants of trading activity. We consider each exchange-month from February 2006 to October 2008 as a separate observation (1363 observations), with consideration to differences in rules over time as well as difference-indifferences regressions and country-dummy variables as well as country fixed-effects. We cluster standard errors by exchange (as in Petersen, 2009), and considered other checks for treating standard errors for panel data sets (e.g., Bertrand et al., 2004), which we found to be quite robust. For each regression, we control for economic factors including market capitalization, market conditions (MSCI index), GDP, and exchange institutional features (Röell, 1992), as well as exchange fixed-effect, and year-effect.

\section{[Insert Table 6 About Here]}

Panel A, B, and C of Table 6 examine the effect of MiFID and exchange trading rules on velocity, volatility, and bid-ask spread, respectively. In each of the three panels we present ten identical regressions to show robustness to alternative specifications. The first two models in each panel present the difference-in-difference regressions. We add an indicator variable (After) which is set to one in the month after November 2008, and zero in all other months. We also include an indicator variable (Treat) which is set to one for exchanges subject to MiFID. The interaction variable labeled Treat*After is the key variable in our experiment. Under the null hypothesis that MiFID encourages trading activity, and reduces market volatility and bid-ask 
spread, we expect the coefficient associated with this variable to be statistically positive in Panel A, but statistically negative in Panel B and C.

In Model (1) of Panel A, the coefficient associated with the interaction variable is 0.087 , significant at the $1 \%$ level, which means that, after November 2007, MiFID exchanges experienced an incremental increase of $8.7 \%$ in velocity compared to non-MiFID exchanges. The effect is estimated at $4.7 \%$ in Model (2) of Panel A, when control variables for surveillance and enforcement are added. Similar results are observed in Panel B and C. After MiFID is put into force, MiFID exchanges see a decrease of $4.1 \%$ (Model 11) to 3.8\% (Model 12) in volatility, significant at the $1 \%$ and 5\% levels, respectively. Panel $\mathrm{C}$ shows that MiFID decreases bid-ask spreads in Europe by a significant 6 (Model 12) to 20 (Model 11) basis points. The evidence is robust to country-dummy variables for each exchange to pick up other exchange-specific factors that can influence market liquidity. As well, the results are robust to controls for changes in economic conditions over time in the MSCI index, differences in market capitalization, market structure, and GDP, among other variables considered, but not included for conciseness. The results provide strong support for our hypothesis that the rules introduced by MiFID helps to enhance market liquidity.

In Models (3) - (9), (13) - (19), and (23) - (29), we assess the impact of each trading rule index on market liquidity measures separately. The liquidity measure is regressed on each index separately along with a group of control variables. Models (10), (20), and (3) consider a number of different indices jointly in the same regression. We do not include every trading rule index jointly in the same regression due to collinearity; rather, we only include the Insider Trading, Price, and Volume Manipulation Rules Indices in the same regression.

Model (3) reports the result of the regression on the Insider Trading Rules Index. Consistent with our hypothesis, trading velocity is 0.069 higher when there is an increase in the Insider Trading Rules Index by one in Model (3), but this effect is marginally insignificant. Likewise, volatility is $2.8 \%$ lower when the Insider Trading Rules Index increases by one (Model 13), and this effect is significant at the $1 \%$ level. Panel C Model (23) indicates that a one point increase in the Insider Trading Rules Index value is associated with a three basis point decrease in the bid-ask spread, and this effect is significant at the 5\% level. One likely explanation for this result is that stricter rules discourage insider trading, which decreases the informational content of spread as well as the spread itself. 
In Models (4) - (6) we observe the Market Manipulation Rules Index, Price Manipulation Rules Index, and Volume Manipulation Rules Index positively associated with velocity, and these effects are significant at the $10 \%$ level in Models (4) and (5) and the $1 \%$ level in Model (6). The effect of the Volume Manipulation Rules Index shows greater economic significance (0.210) relative to that of Market Manipulation Rules Index (0.013) and Price Manipulation Rules Index (0.021). When these variables are combined together in Model (10), the Volume Manipulation Rules Index is statistically significant at the $1 \%$ level and the other trading rule indices are insignificant. The Spoofing and False Disclosure Rules Indices in Models (7) and (8) are statistically insignificant, and the Broker-Agency Conflict Rules Index is negative and significant (although the latter variable is insignificant in a more parsimonious specification).

The Broker-Agency Conflict Rules Index is not statistically significant for liquidity in each panel. One likely explanation for this result is that traders and/or brokers are bound by rules of conduct formulated by professional associations that vary from country to country, span different countries, and have different affiliations within each country. ${ }^{11}$ Importantly, this finding highlights the fact that the significance of the Insider Trading Rules Index and the Market Manipulation Rules Index (and its subcomponents) is not merely a spurious indication that detailed rule drafters are more likely to reside in certain countries, as the details regarding brokeragency conflict are not statistically related to trading velocity.

In Panel B Models (13) - (19), volatility is negatively associated with all four market manipulation rules indices but not with the Broker-Agency Conflict Rules Index. All coefficients are significant at the $1 \%$ level except the False Disclosure Rules Index, which is significant at $10 \%$ level. The results are stronger for the Volume Manipulation Rules Index (4.3\% economic significance). But in Model (20) when indices are combined in the same regression, the Price Manipulation Rules Index is the one that remains statistically significant and shows a $1.5 \%$ drop in volatility for a one point increase in the index.

In Panel C, Models (23) - (30) show that, among the different indices, the Insider Trading Rules Index is most closely statistically and negatively related to the bid-ask spread. An

\footnotetext{
11 A second explanation is that brokers play less of a role as a financial intermediary offering advice in some countries, such as China. We considered this possibility by excluding such countries and found the results to be very similar.
} 
increase in the Insider Trading Rules Index by one point reduces the bid-ask spread by 3.14 basis points in Model (23) and 4.77 basis points in Model (30) and these effects are significant at the $5 \%$ and $1 \%$ levels, respectively.

In all models, except Models (1), (11) and (21), we add the surveillance variable in order to control for the potential influence of the detection of illegal-trading behaviors on the inferences (as in Cumming and Johan, 2008). In addition, we also add a variable for the Efficiency of the Judiciary as a proxy for enforcement. Further, in Models (10), (20) and (30) we add the Investor Protection Index (defined in Table 1). The latter two variables are more closely related to the enforcement of corporate governance rules against corporate self-dealing and the expense of outside shareholders, and as such are imperfect proxies for the enforcement of secondary trading rules. We consider other variables from La Porta et al. (2006) and Jackson and Roe (2009) but they do not materially impact our analyses pertaining to the trading-rules variables of interest. We note that the inclusion of these control variables in the regression has no effect on the statistical significance of the Treat*After interaction term, although the magnitude of the changes is reduced in Panels A and C and slightly reduced in Panel B: see Models (1) versus (2), (11) versus (12), and (21) versus (22). The coefficient of surveillance variable generally shows a significant improvement in liquidity, consistent with Cumming and Johan (2008). The negative and significant coefficient for the efficiency of the judiciary supports La Porta et al. $(1998,2006)$. The Investor Protection Index coefficient estimate in Model (10) is sensitive to the other included variables; for example if we exclude the Efficiency of the Judiciary variable then the Investor Protection Index is positive and significant. But regardless, the addition or subtraction of these or other variables does not materially impact our reported results for the trading rule indices. ${ }^{12}$

A number of our additional control variables for market microstructure, market conditions, and other country factors are statistically significant. For example, velocity and volatility are greater for our various proxies for exchange size, and bid-ask spreads are smaller. However, when we add or subtract other microstructure variables (e.g., such as those in Panel C) in any of the Models (1) - (30) and country or market variables, we do not find different results pertaining to our findings regarding trading rules.

12 The Public Enforcement Index (La Porta et al. 2006) has a 0.72 correlation with the Investor Protection Index. Inclusion of this variable influences the coefficient estimates for the Investor Protection Index, but does not influence the other variables of interest in our analyses. Similarly, the inclusion or exclusion Criminal Enforcement Index (La Porta et al. 2006) and additional variables from Jackson and Roe (2009) were immaterial to our inferences drawn from the trading rules indices. 
In summary, Table 6 indicates that a variety of specifications that include exchangedummy variables, exchange fixed-effects, exchange institutional features, and surveillance applications, among other things, show that trading rules facilitate trading velocity, reduce market volatility, and reduce trading cost across exchanges and over time. In general, MiFID is an important factor in terms of improving market activities as evidenced by our difference-indifferences regressions. Considering different indices in the same regression, the Volume Manipulation Rules Index is most closely connected to trading velocity, the Price Manipulation Rules index is most closely connected to volatility, and the Insider Trading Rules Index is most closely connected to bid-ask spreads. Overall, insider trading rules and market manipulation rules are important for facilitating trading activity and decreasing volatility.

Further to our cross-sectional and time series specifications in Table 6, in a prior version of the paper we reported cross-sectional regressions (42 observations) following nearly identical methods as in La Porta et al. (2006). Also, we considered the use of instruments as in La Porta et al. Further, we presented partial regression plots for some of the trading rule indices. Those results are available on request and consistent with the findings reported here. As well, we note that we considered other robustness checks not presented herein, such as excluding various exchanges from the analyses, two-step regression methods to account for missing observations, and subsamples with different time periods. Again, those checks showed results that are quite consistent with the findings presented herein.

\section{Conclusions}

In this paper, we contribute to the literature on international differences in stock exchanges by examining the effect of trading rules on liquidity as represented by velocity, volatility and bid-ask spread. Building on prior work on mandatory disclosure and delegation between private and public enforcement of securities laws (La Porta et al., 2006; Hail and Leuz, 2006; Jackson and Roe, 2009) and surveillance technology and information sharing in ex post enforcement (Cumming and Johan, 2008), in this paper, we consider the interaction between rule specificity in stock exchange trading rules and stock exchange trading activity.

We employ a sample of 42 exchanges around the world and find that stock exchange trading activity is most closely related to trading rules specificity in regard to insider trading and 
market manipulation, but is not statistically related to rules pertaining to broker-agency conflict. The reasoning behind this finding is that insider trading and market manipulation rules provide clarity regarding prohibited manipulative trading practices and are of direct and central importance to the conduct of market participants. By contrast, broker-agency conflict rules are typically subject to extraneous rules from governing bodies and professional associations for brokers (such as the Chartered Financial Analysts Institute). The connection between trading activity and insider trading and market manipulation rules is robust to concerns about endogeneity, difference-in-differences specifications, and alternative control variables. Specifically, we observe the material impact of the MiFID rule changes on all dimensions of liquidity. Although it is difficult to isolate precisely the components of trading rules that matter the most, it is noteworthy that we do observe a close connection between the Volume Manipulation Rules Index and trading velocity, the Price Manipulation Rules index and volatility, and the Insider Trading Rules Index and bid-ask spreads. The results indicate trading rules are an important source of information to consider in explaining the differences in trading activity among stock exchanges around the world. Future work might look to the exchange trading rules as a source of international differences in stock exchanges, market efficiency, and market integrity.

\section{References}

Aitken, M., Siow, A., 2003. Ranking equity markets on the basis of market efficiency and integrity. In: H. Skeete, Hewlett-Packard Handbook of World Stock, Derivative \& Commodity Exchanges 2003. Dublin, pp. xliv-lv.

Aggarwal, R., 2001. Regulatory infrastructure covering financial markets. Brookings-Wharton Papers on Financial Services, 55-76.

Aggarwal, R.K., Wu, G., 2003. Stock market manipulation - theory and evidence. AFA 2004 San Diego Meetings. Available at SSRN: http://ssrn.com/abstract=474582

Allen, F., Gale, D., 1992. Stock-price manipulation. Review of Financial Studies 5, 503-529.

Allen, F., Gorton, G., 1992. Stock price manipulation, market microstructure and asymmetric information. European Economic Review 36, 624-630.

Amihud, Y., and Mendelson, H., 1998. Liquidity and asset prices: financial management implications, Financial Management 17, 5-15.

Avgouleas, E., 2005. The mechanics of regulation of market abuse. Oxford University Press, UK.

Beny, L.N., 2005. Do insider trading laws matter? Some preliminary comparative evidence, American Law and Economics Review 7, 144-183. 
Bertrand, M., Duflo, E., Mullainathan, S., 2004. How much should we trust difference in difference estimates? Quarterly Journal of Economics 119, 249-275.

Carson, J.W., 2003. Conflicts of interest in self-regulation: can demutualized exchanges successfully manage them? Unpublished working paper No. 3183. World Bank Policy Research, Washington DC.

Chordia, T., Roll, R., Subrahmanyam, A., 2002. Order imbalance, liquidity, and market returns. Journal of Financial Economics 65, 111-130.

Clayton, M.J., Jorgensen, B.N., Kavajecz, K.A., 2006. On the presence and market-structure of exchanges around the world, Journal of Financial Markets 9, 27-48.

Comerton-Forde, C, Rydge, J., 2006. Market integrity and surveillance effort. Journal of Financial Services Research 29, 149-172.

Comerton-Forde, C., Tang, K., 2007. Anonymity, frontrunning and market integrity. Journal of Trading 4, 101-118.

Cumming, D., Johan, S.A., 2008. Global market surveillance. American Law and Economics Review, 10, 454-506.

Daouk, H., Lee, C.M.C., Ng, D.T., 2006. Capital market governance: how do security laws affect market performance? Journal of Corporate Finance 12, 560-593.

Daske, H., Hail, L., Leuz, C., Verdi, R.S., 2008. Mandatory IFRS reporting around the world: Early evidence on the economic consequences. Journal of Accounting Research 46, $1085-1142$

DeMarzo, P.M., Fishman, M.J., Hagerty, K.M., 2005. Self-regulation and government oversight. Review of Economic Studies 72, 3, 687-706.

Ferguson, M.F., Peters, S.R., 2003. But I know it when I see it: An economic analysis of vague rules. Unpublished working paper. University of Cincinnati and Kansas State University.

Gerard, B., Nanda, V., 1993. Trading and manipulation around seasoned equity offerings. Journal of Finance 48, 213-245.

Hail, L., Leuz, C., 2006. International differences in the cost of equity capital: do legal institutions and securities regulation matter? Journal of Accounting Research 44, 485531 .

Harris, D., 2006. The impact of hot issue markets and noise traders on stock exchange listing standards. University of Toronto Law Journal 56, 223-280.

Harris, L., 2002. Trading and exchanges: market microstructure for practitioners. Oxford University Press, UK. 
Harris, F.H.deB., Aitken, M.A., Cook, R.M., McInish, T.H., 2008. Market design and execution costs for matched securities worldwide. Institutional Investor's Guide to Global Liquidity, Vol 2, Goldman Sachs.

Hillion, P., Suominen, M., 2004. The manipulation of closing prices. Journal of Financial Markets 7, 351-375.

Jackson, H.E., Roe, M.J., 2009. Public and private enforcement of securities laws: resource-based evidence, Journal of Financial Economics, forthcoming.

Jarrow, R.A. 1992. Market manipulation, bubbles, corners and short squeezes. Journal of Financial and Quantitative Analysis 27, 311-336.

Jarrow, R.A., 1994. Derivative security markets, market manipulation and option pricing theory. Journal of Financial and Quantitative Analysis 29, 241-261.

Kumar, P, Seppi, D.J., 1992. Futures manipulation with cash settlement. Journal of Finance 47, 1485-1502.

La Porta, R., Lopez-de-Silanes, F., Shleifer, A., 1999. Corporate ownership around the world. Journal of Finance 54, 471-517.

La Porta, R., Lopez-de-Silanes, F., Shleifer, A., 2006. What works in securities laws? Journal of Finance 61, 1-32.

La Porta, R., Lopez-de-Silanes, F., Shleifer, A., Vishny, R., 1997. Legal determinants of external finance. Journal of Finance 52, 1131-1150.

La Porta, R., Lopez-de-Silanes, F., Shleifer, A., Vishny, R., 1998. Law and finance. Journal of Political Economy 106, 1113-1155.

La Porta, R., Lopez-de-Silanes, F., Shleifer, A., Vishny, R., 2002. Investor protection and corporate valuation. Journal of Finance 57, 1147-1170.

Laffont, J.-J., Tirole, J., 1993. A Theory of Incentives in Procurement and Regulation. MIT Press, Cambridge, MA.

Lampert, R., Leuz, C., Verracchia, R.E., 2007. Accounting information, disclosure, and the cost of capital. Journal of Accounting Research 45, 385-420.

Madhavan, A., Porter, D., Weaver, D., 2005. Should securities markets be transparent? Journal of Financial Markets 8, 266-288.

Mahoney, P.G., 1999. The stock pools and the Securities Exchange Act. Journal of Financial Economics 51, 343-369.

Massimb, M. N., Phelps, B. D., 1994. Electronic trading, market structure and liquidity. Financial Analyst Journal 50, 39-50. 
Merrick, J.J. Jr., Naik, N.Y. ,Yadav P.K., 2005. Strategic trading behavior and price distortion in a manipulated market: anatomy of a squeeze. Journal of Financial Economics 77, 171218.

Ni, S.X., Pearson, N.D., Poteshman, A.M., 2005. Stock Price Clustering on Option Expiration Dates. Journal of Financial Economics 78, 49-87.

O'Hara, M., Mendiola, A.M., 2003. Taking stock in stock markets: the changing governance of exchanges. Unpublished working paper. Cornell University, NY.

Peng, L., and Röell, A., 2009. Managerial incentives and stock price manipulation, CEPR Discussion Paper No. DP7442.

Pagano, M., O. Randl, A.A. Röell and J. Zechner, 2001. What makes stock exchanges succeed? Evidence from cross-listing decisions. European Economic Review 45, 770-782.

Pagano, M.., A. Röell and J. Zechner, 2002. The geography of equity listing: Why do companies list abroad?, Journal of Finance 57, 2651-2694.

Petersen, M.A., 2009. Estimating standard errors in finance panel data sets: comparing approaches. Review of Financial Studies 22, 435-480.

Pirrong, S.C., 1993. Manipulation of the commodity futures market delivery process. Journal of Business 15, 335-370.

Pirrong, S.C., 1995a. The self-regulation of commodity exchanges: the case of market manipulation, Journal of Law and Economics 38, 141-206.

Pirrong, S.C., 1995b. Mixed manipulation strategies in commodity futures markets. Journal of Futures Markets 15, 13-38.

Pirrong, C., 1999. The organization of financial exchange markets: theory and evidence, Journal of Financial Markets 2, 329-357.

Pirrong, S.C., 2004. Detecting manipulation in futures markets: the Ferruzi soybean episode. American Law and Economics Review 6, 28-71.

Pistor, K., Keinan, Y., Kleinheisterkamp, J., West, M., 2003. The evolution of corporate law: a cross-country comparison. Journal of International Economic Law 23, 791-871.

Pistor, K., Xu, C., 2003. Incomplete law - a conceptual and analytical framework and its application to the evolution of financial market regulation. Journal of International Law and Politics 35, 931-1013.

Pistor, K., Xu, C., 2005. Governing stock markets in transition economies: lessons from China. American Law and Economics Review 7,184-210.

Pritchard, A. C., 2003. Self-regulation and securities markets. Regulation 26 (1), 32-39.

Reiffen, D. Robe, M.A., 2007. Ownership structure and enforcement incentives at self-regulatory financial exchanges. Unpublished working paper, American University, Washington DC. 
Röell, A., 1992. "Comparing the performance of stock exchange trading systems," In: J. Fingleton and D. Schoenmaker, (Eds.), The Internationalisation of Capital Markets and the Regulatory Response. Kluwer, Amsterdam.

Romano, R., 1993. The Genius of American Corporate Law. AEI Press, Washington, DC.

Romano, R., 2001. The need for competition in international securities regulation. Theoretical Inquiries in Law 2, 1-179.

Romano, R., 2002. The Advantage of Competitive Federalism for Securities Regulation. AEI Press, Washington DC.

Roll, R., 1988. The international crash of 1987. Financial Analysts Journal 44, 19-35.

Spamann, H., 2009. The 'antidirector rights index' revisited. Review of Financial Studies, forthcoming.

Stevenson, D., 2005. Toward a new theory of notice and deterrence. Cardozo Law Review 26, $1535-1594$.

Stoll, H. R. 2000. Friction. Journal of Finance 55, 1479-1514.

Vitale, P., 2000. Speculative noise trading and manipulation in the foreign exchange market. Journal of International Money and Finance 19, 689-712.

World Federation of Exchanges, 2006-2008. Annual Report and Statistics. http://www.worldexchanges.org/ 
Table 1. Definition of Variables

This table defines the variables, including the trading rule indices. Variables used in subsequent tables are highlighted in bold font.

\begin{tabular}{c}
\hline Variable Name \\
\hline Insider Trading Rules \\
Front-running \\
Client Precedence \\
Trading Ahead of Research \\
Reports \\
Separations of Research and \\
Trading \\
Broker Ownership Limit \\
Restrictions on Affiliation
\end{tabular}

Restrictions on Communications

Investment Company Securities

Influencing or Rewarding

Employees of Others

Anti-Intimidation/ Coordination

Insider Trading Rules Index

Price Manipulation Rules

Marking the Open

Marking the Close

Misleading End of the Month/Quarter/Year Trades

Intraday

Ramping/ Gouging

Market Setting

Pre-Arranged Trades

Domination and Control

Price Manipulation Rules Index

Volume Manipulation Rules

Churning

Wash Trade

Volume Manipulation Rules

Index
Definition

A dummy variable equal to one if the trading rules explicitly prohibit a broker's house or employee account from buying/selling in a period shortly prior to significant buying/selling by a client.

A dummy variable equal to one if the trading rules explicitly prohibit a broker from violating the time priority of client orders.

A dummy variable equal to one if the trading rules explicitly prohibit brokers with proprietary access to research reports from trading ahead of the release of the research report.

A dummy variable equal to one if the trading rules specify that research departments and trading departments must have a 'Chinese wall' separating these departments.

A dummy variable equal to one if the trading rules specify maximum ownership limits for brokerages and/or employees with respect to any given security.

A dummy variable equal to one if the trading rules specify limits or restrictions on affiliation between exchange members and member companies.

A dummy variable equal to one if the trading rules specify limits or restrictions on brokerages' communications with the public.

A dummy variable equal to one if the trading rules specify restrictions or bans on the trading of members' own or affiliated investment company securities.

A dummy variable equal to one if the trading rules specify bans on any means of influencing or rewarding employees of other members or member companies.

A dummy variable equal to one if the trading rules specify bans on any form of intimidation of or coordination with other members or member companies.

Sum of dummy variables for Front-running, Client Precedence, Trading Ahead of Research Reports, Separation of Research and Trading, Broker Ownership Limit, Restrictions on Affiliation, Restrictions on Communications, Investment Company Securities, Influencing or Rewarding the Employees of Others, and Anti-Intimidation / Coordination.

A dummy variable equal to one if the trading rules explicitly prohibit the placing of purchase orders at slightly higher prices or sale orders at lower prices to drive up/suppress the price of the securities when the market opens.

A dummy variable equal to one if the trading rules explicitly prohibit the buying or selling of securities at the close of the market in an effort to alter the closing price of the security.

A dummy variable equal to one if the trading rules explicitly prohibit transactions executed at a particular date to establish gains or losses or conceal portfolio losses or true positions in connection with end of the month/quarter/year.

A dummy variable equal to one if the trading rules explicitly prohibit the execution of a series of trades over a short time period that generates a price movement over that period in which it is unusual, given the trading history of the security.

A dummy variable equal to one if the trading rules explicitly prohibit market setting by crossing in the short term, high or low. For example, this could be done to set the VWAP (volume weighted average price) or cross market (setting the price in one market to justify crossing in the follow-on market).

A dummy variable equal to one if the trading rules explicitly prohibit pre-arranged trades within an extremely short time period whereby the client broker and another broker enter a bid and ask for the same volume and price, which then generates a trade between the two brokers for the whole of the volume. The volume of the order must be significant given the trading history of the security.

A dummy variable equal to one if the trading rules explicitly prohibit a broker/client from generating significantly greater price changes in a security, possibly for corners (securing control of the bid/demand-side of both the derivative and the underlying asset, and the dominant position can be exploited to manipulate the price of the derivative and/or the asset), squeezes (taking advantage of a shortage in an asset by controlling the demand-side and exploiting market congestion during such shortages in a way as to create artificial prices), and mini-manipulations (trading in the underlying security of an option in order to manipulate its price so that the options will become in-the-money).

Sum of dummy variables for Marking the Open, Marking the Close, Misleading End of the Month/Quarter/Year Trades, Intraday Ramping / Gouging, Market Setting, Pre-arranged Trades, and Domination and Control.

A dummy variable equal to one if the trading rules explicitly prohibit excessive buying and selling of stocks by a trader such as a broker in order to generate large commission fees (in the case of churning client accounts) and/or the appearance of significant volume (in the case of churning house accounts and/or churning client accounts)

A dummy variable equal to one if the trading rules explicitly prohibit the same client reference on both sides of a trade.

Sum of dummy variables for Churning and Wash Trade. 
Table 1. (Continued)

\begin{tabular}{c|l}
\hline Variable Name & Definition \\
\hline Spoofing Rules & $\begin{array}{l}\text { A dummy variable equal to one if the trading rules explicitly prohibit brokers from giving up priority, such as entering a } \\
\text { bid/ask for a significant quantity at a price away from priority and then both cancelling this order as it approaches } \\
\text { priority, and re-entering the order shortly thereafter at a price level further away from priority. }\end{array}$
\end{tabular}

Switch

Layering of Bids/Asks

Spoofing Rules Index

False Disclosure Rules

Dissemination of False and Misleading Information

Parking or Warehousing

\section{False Disclosure Rules Index}

\section{Market Manipulation Rules Index}

Broker-Agency Rules

Trade Through

Improper Execution

Restrictions on Member Use of Exchange

Name

Restrictions on Sales Materials and Telemarketing

Fair Dealing with Customers

\section{Broker-Agency Index}

Surveillance, Efficiency of Judiciary, and Investor Protection Indices

Surveillance Index

Efficiency of the Judiciary Index

Investor Protection Index

$\underline{\text { Market Statistics }}$

Velocity

Volatility

Bid-Ask Spread
A dummy variable equal to one if the trading rules explicitly prohibit brokers from entering fictitious orders, such as entering a significant quantity at or close to priority, then completing a trade on the opposite side of the market, and thereafter deleting the original order shortly after the completion of the opposite order.

A dummy variable equal to one if the trading rules explicitly prohibit brokers from layering bids/asks, such as stagger orders from the same client reference at different price and volume levels, with the intent of giving a false or misleading appearance with respect to the market for the security.

Sum of dummy variables for Giving up Priority, Switch and Layering of Bids/Asks.

A dummy variable equal to one if the trading rules explicitly prohibit the dissemination of false or misleading market information.

A dummy variable equal to one if the trading rules explicitly prohibit hiding the true ownership of securities by creating a set of fictitious transactions and trades.

Sum of dummy variables for Dissemination of False and Misleading Information and Parking or Warehousing.

Sum of Price Manipulation Rules Index, Volume Manipulation Rules Index, Spoofing Rules Index, and False Disclosure Rules Index.

A dummy variable equal to one if the trading rules explicitly prohibit the completion of a client's order at a price inferior to the best posted bid or ask; e.g., the market maker who received the order is unable or unwilling to fill it at the best posted bid or ask price, and hence the trade is instead executed at the market maker's price.

A dummy variable equal to one if the trading rules explicitly prohibit brokers from charging fees for completing a client order are unwarranted given the circumstances.

A dummy variable equal to one if the trading rules specify restrictions on exchange members' use of the exchange name.

A dummy variable equal to one if the trading rules specify restrictions on exchange members' nature of sales and telemarketing.

A dummy variable equal to one if the trading rules specify details with respect to the "know your client rule" that requires brokerages to not make trades that do not fit within the clients interest, no delays in the handling of client orders, and the like.

Sum of dummy variables for Trade Through, Improper Execution, Restrictions on Member Use of Exchange Name, Restrictions on Sales Materials and Telemarketing, and Fair Dealing with Customers.

The principal component of (1) single market surveillance and (2) cross market surveillance. Source: Cumming and Johan (2008). Available for a subset of countries, and provided contingent on maintaining confidentiality and anonymity as exchanges do not want market participants to know all of the things they do and do not look for in their surveillance.

Assessment of the efficiency and integrity of the legal environment. Scale from zero to 10; with lower scores, lower efficiency levels. Source: La Porta et al. (1998).

The principal component of (1) Anti-Director Rights, (2) Disclosure Requirements, and (3) Liability Standards. Sources: La Porta et al. (2006), Spamann (2009).

The ratio between the turnover of domestic shares and their market capitalization. The value is annualized by multiplying the monthly moving average by 12, according to the following formula: Monthly Domestic Share Turnover / Month-end Domestic Market Capitalization. Only domestic shares are used in order to be consistent. Source: World Federation of Exchanges (2006-2008).

Volatility of each firm is calculated using the prior 60 month returns. For each exchange, the volatility is the firm market capitalization weighted average of the volatilities of the firms consisting of average, and then annualized. Firm market capitalization is equal to the product of month-end shares outstanding and stock prices, or the mid-price of bid and ask prices, if stock price is missing. The monthly return, share outstanding and stock price are from Thomson Reuters Datastream.

The relative quoted spread of each firm is the difference between the monthly bid and ask prices, divided by the midpoint price. For each exchange, the relative quoted spread is the firm market capitalization weighted average of the spreads of the firms that its major index consists of. Firm market capitalization is equal to the product of month-end shares outstanding and stock prices, or the mid-price of bid and ask prices, if stock price is missing. The bid and ask prices, shares outstanding, and stock prices are from Thomson Reuters Datastream. 
Table 1. (Continued)

\begin{tabular}{|c|c|}
\hline Variable Name & Definition \\
\hline Log (Market Capitalization) & $\begin{array}{l}\text { Log of domestic market capitalization in USD millions in the same period relative to the measure of velocity. Market } \\
\text { capitalization is from World Federation of Exchanges }(2006-2008) \text {. }\end{array}$ \\
\hline Hybrid Exchange & A dummy variable equal to one for exchanges with both floor trading and limit order book. \\
\hline Log (Volume) & $\begin{array}{l}\text { Log of total value of shares trading in USD millions in the same period relative to the measure of velocity. Total value of } \\
\text { share trading data is from World Federation of Exchanges (2006-2008). }\end{array}$ \\
\hline Log (Number of Trades) & $\begin{array}{l}\text { Log of total number of trades in thousands in the same period relative to the measure of velocity. Numbers of trades are } \\
\text { from World Federation of Exchanges (2006-2008). }\end{array}$ \\
\hline $\log (1+\mathrm{MSCI})$ & Log of one plus the MSCI index in the lagged period relative to the measure of velocity \\
\hline $\log ($ GDP) & Log of GDP per capita in the lagged period relative to the measure of velocity \\
\hline
\end{tabular}


Table 2. Trading Rule Indices

This table summarizes the index values for the trading rules for each exchange, as defined in Table 1 . Values are presented for 2008 . The $*$, **,*** denote significance at the $10 \%, 5 \%$, and $1 \%$ levels, respectively.

\begin{tabular}{|c|c|c|c|c|c|c|c|}
\hline Exchange & $\begin{array}{c}\text { Price } \\
\text { Manipulation } \\
\text { Index }\end{array}$ & $\begin{array}{c}\text { Volume } \\
\text { Manipulation } \\
\text { Index }\end{array}$ & $\begin{array}{c}\text { Spoofing } \\
\text { Index }\end{array}$ & $\begin{array}{c}\text { False } \\
\text { Disclosure } \\
\text { Index } \\
\end{array}$ & $\begin{array}{c}\text { Market } \\
\text { Manipulation } \\
\text { Index }\end{array}$ & $\begin{array}{c}\text { Insider } \\
\text { Trading } \\
\text { Index }\end{array}$ & $\begin{array}{c}\text { Broker } \\
\text { Agency } \\
\text { Index } \\
\end{array}$ \\
\hline \multicolumn{8}{|l|}{ English Legal Origin } \\
\hline Australia & 3 & 1 & 2 & 0 & 6 & 2 & 0 \\
\hline Bermuda & 2 & 1 & 1 & 1 & 5 & 2 & 2 \\
\hline Bombay & 0 & 1 & 1 & 1 & 3 & 2 & 3 \\
\hline Canada & 7 & 2 & 3 & 0 & 12 & 2 & 1 \\
\hline Hong Kong & 3 & 2 & 1 & 1 & 7 & 0 & 0 \\
\hline India NSE & 3 & 1 & 1 & 1 & 6 & 3 & 3 \\
\hline Ireland & 7 & 1 & 3 & 1 & 12 & 2 & 0 \\
\hline Israel & 2 & 0 & 0 & 1 & 3 & 1 & 0 \\
\hline London & 7 & 2 & 3 & 1 & 13 & 3 & 0 \\
\hline Malaysia & 0 & 0 & 1 & 1 & 2 & 7 & 2 \\
\hline NASDAQ & 5 & 1 & 3 & 2 & 11 & 10 & 5 \\
\hline New Zealand & 2 & 0 & 1 & 1 & 4 & 3 & 3 \\
\hline NYSE & 6 & 2 & 3 & 2 & 13 & 7 & 3 \\
\hline Singapore & 3 & 1 & 2 & 1 & 7 & 2 & 2 \\
\hline Sri Lanka & 2 & 1 & 0 & 1 & 4 & 4 & 2 \\
\hline Thailand & 4 & 2 & 1 & 1 & 8 & 1 & 0 \\
\hline Average English Legal Origin & 3.50 & 1.13 & 1.63 & 1.00 & 7.25 & 3.19 & 1.63 \\
\hline \multicolumn{8}{|l|}{$\underline{\text { French Legal Origin }}$} \\
\hline Argentina & 2 & 0 & 1 & 0 & 3 & 3 & 1 \\
\hline Brazil & 0 & 0 & 1 & 0 & 1 & 1 & 0 \\
\hline Chile & 0 & 0 & 0 & 0 & 0 & 0 & 0 \\
\hline Columbia & 2 & 0 & 0 & 0 & 2 & 0 & 0 \\
\hline Egypt & 2 & 0 & 0 & 0 & 2 & 0 & 0 \\
\hline France & 7 & 1 & 3 & 2 & 13 & 2 & 0 \\
\hline Greece & 7 & 1 & 3 & 1 & 12 & 3 & 0 \\
\hline Indonesia & 1 & 0 & 1 & 1 & 3 & 2 & 1 \\
\hline Italy & 7 & 1 & 3 & 1 & 12 & 3 & 0 \\
\hline Jordan & 1 & 0 & 1 & 0 & 2 & 5 & 3 \\
\hline Mexico & 3 & 1 & 1 & 1 & 6 & 2 & 0 \\
\hline Peru & 0 & 0 & 0 & 0 & 0 & 0 & 0 \\
\hline Philippines & 0 & 0 & 0 & 0 & 0 & 0 & 0 \\
\hline Spain & 7 & 1 & 3 & 1 & 12 & 4 & 0 \\
\hline Turkey & 0 & 0 & 0 & 0 & 0 & 0 & 0 \\
\hline Average French Legal Origin & 2.60 & 0.33 & 1.13 & 0.47 & 4.53 & 1.67 & 0.33 \\
\hline
\end{tabular}




\begin{tabular}{|c|c|c|c|c|c|c|c|}
\hline Exchange & $\begin{array}{c}\text { Price } \\
\text { Manipulation } \\
\text { Index } \\
\end{array}$ & $\begin{array}{c}\text { Volume } \\
\text { Manipulation } \\
\text { Index } \\
\end{array}$ & $\begin{array}{c}\text { Spoofing } \\
\text { Index }\end{array}$ & $\begin{array}{c}\text { False } \\
\text { Disclosure } \\
\text { Index } \\
\end{array}$ & $\begin{array}{c}\text { Market } \\
\text { Manipulation } \\
\text { Index } \\
\end{array}$ & $\begin{array}{c}\text { Insider } \\
\text { Trading } \\
\text { Index } \\
\end{array}$ & $\begin{array}{c}\text { Broker } \\
\text { Agency } \\
\text { Index } \\
\end{array}$ \\
\hline \multicolumn{8}{|l|}{$\underline{\text { German Legal Origin }}$} \\
\hline Austria & 7 & 1 & 3 & 1 & 12 & 2 & 0 \\
\hline Germany & 7 & 1 & 3 & 1 & 12 & 3 & 0 \\
\hline Korea & 4 & 2 & 2 & 1 & 9 & 3 & 2 \\
\hline Shanghai & 2 & 1 & 1 & 1 & 5 & 2 & 0 \\
\hline Shenzhen & 2 & 1 & 1 & 1 & 5 & 2 & 0 \\
\hline Slovenia & 7 & 1 & 3 & 2 & 13 & 3 & 0 \\
\hline Switzerland & 7 & 1 & 3 & 1 & 12 & 3 & 1 \\
\hline Taiwan & 2 & 0 & 0 & 0 & 2 & 0 & 0 \\
\hline Tokyo & 1 & 0 & 1 & 0 & 2 & 1 & 0 \\
\hline Average German Legal Origin & 4.33 & 0.89 & 1.89 & 0.89 & 8.00 & 2.11 & 0.33 \\
\hline \multicolumn{8}{|l|}{$\underline{\text { Scandinavian Legal Origin }}$} \\
\hline OMX & 7 & 1 & 3 & 1 & 12 & 5 & 2 \\
\hline Oslo & 7 & 1 & 3 & 1 & 12 & 4 & 0 \\
\hline Average Scandinavian Legal Origin & 7.00 & 1.00 & 3.00 & 1.00 & 12.00 & 4.50 & 1.00 \\
\hline \multicolumn{8}{|l|}{ Tests of Means } \\
\hline English versus Civil Law & -0.05 & $2.58^{* *}$ & 0.23 & $1.94 *$ & 0.68 & 1.58 & $2.98^{* * *}$ \\
\hline English versus French & 0.91 & 0.92 & 0.54 & 0.62 & $2.59 * *$ & 1.56 & 1.40 \\
\hline English versus German & -0.83 & 0.27 & -0.28 & 0.13 & -0.71 & 1.11 & 1.40 \\
\hline English versus Scandinavian & $-3.70^{* * *}$ & 0.15 & -1.57 & 0.00 & $-4.77 *$ & -1.34 & 0.62 \\
\hline French versus German & $-1.71 *$ & -0.64 & -0.81 & -0.48 & $-3.23^{* * *}$ & -0.47 & 0.00 \\
\hline French versus Scandinavian & $-4.53^{* * *}$ & -0.82 & $-2.09 * *$ & -0.64 & $-7.27^{* * * *}$ & $-2.95^{* * *}$ & -0.67 \\
\hline German versus Scandinavian & $-2.70 * *$ & -0.13 & -1.22 & -0.13 & $-3.84 * * *$ & $-2.51 * *$ & -0.66 \\
\hline
\end{tabular}


Table 3. Descriptive Statistics

This table presents statistics for the full sample of country-month observations in the data. The data span the months from February 2006 - October 2008, and the exchanges listed in Table 2. The full number of country-months in the data is 1386, but for some variables there are missing data. Velocity data from the World Federation of Exchanges are not available for Jordan prior to 2008. Bid-ask-spread data from Datastream are missing for Argentina, Athens, Bermuda, Chile, Columbia, India Bombay, India NSE, Israel, and Peru. Volatility data is missing for selected months for Athens, Bermuda, and Bombay, India. Surveillance data are available for select countries from Cumming and Johan (2008) as indicated in Table 1. World Federation of Exchanges has incomplete data on the number of trades for Italy, Bermuda, Japan, Jordan, and Singapore for select months, and similarly for a few observations for market capitalization and volume.

\begin{tabular}{c|cccccc}
\hline & Mean & Median & $\begin{array}{c}\text { Standard } \\
\text { Deviation }\end{array}$ & Minimum & Maximum & $\begin{array}{c}\text { Number of } \\
\text { Observations }\end{array}$ \\
\hline Velocity & 0.910 & 0.709 & 0.632 & 0.115 & 2.183 & 1363 \\
Volatility & 0.319 & 0.295 & 0.083 & 0.211 & 0.485 & 1319 \\
Bid-Ask Spread & 0.007 & 0.004 & 0.007 & 0.001 & 0.074 & 988 \\
Insider Trading Rules Index & 2.249 & 2 & 2.109 & 0 & 10 & 1386 \\
Market Manipulation Rules Index & 5.212 & 4 & 4.024 & 0 & 13 & 1386 \\
Price Manipulation Rules Index & 2.600 & 2 & 2.259 & 0 & 7 & 1386 \\
Volume Manipulation Rules Index & 0.680 & 1 & 0.710 & 0 & 2 & 1386 \\
Spoofing Rules Index & 1.238 & 1 & 1.011 & 0 & 3 & 1386 \\
False Disclosure Rules Index & 0.695 & 1 & 0.585 & 0 & 2 & 1386 \\
Broker Agency Rules Index & 0.872 & 0 & 1.260 & 0 & 5 & 1386 \\
Surveillance & 24.867 & 23.307 & 11.378 & 6.659 & 42.994 & 159 \\
Efficiency of the Judiciary & 7.815 & 8 & 1.994 & 2.5 & 10 & 1386 \\
Investor Protection Index & 2.321 & 2.272 & 0.838 & 0.686 & 3.775 & 1386 \\
Log (Market Capitalization) & 12.819 & 12.821 & 1.843 & 7.619 & 16.625 & 1361 \\
Hybrid Exchange & 0.359 & 0 & 0.480 & 0 & 1 & 1386 \\
Log (Volume) & 9.974 & 10.146 & 2.720 & 0.000 & 15.168 & 1361
\end{tabular}


Table 4. Comparison Tests

This table presents the comparison of means and medians tests for velocity (Panel A), volatility (Panel B), and the bid-ask spread (Panel C) for different cut-off values of the indices defined in Table 1. In each Panel, Part 1 considers all exchanges in the dataset, Part 2 considers the subset of exchanges for which MiFID applies, and Part 3 considers pre- versus post- MiFID for the subsample of MiFID and non-MiFID exchanges. The *,**,*** denote significance at the $10 \%, 5 \%$, and $1 \%$ levels, respectively

\section{Panel A. Comparison Tests for Velocity}

\begin{tabular}{|c|c|c|c|c|c|c|c|c|c|c|c|c|c|c|c|c|}
\hline \multirow[t]{2}{*}{$\underline{\text { Part 1. All Countries }}$} & \multicolumn{2}{|c|}{$\begin{array}{c}\text { Insider } \\
\text { Trading Index }\end{array}$} & \multicolumn{2}{|c|}{$\begin{array}{l}\text { Market Manipulation } \\
\text { Index }\end{array}$} & \multicolumn{2}{|c|}{ Price Manipulation Index } & \multicolumn{2}{|c|}{$\begin{array}{c}\text { Volume } \\
\text { Manipulation } \\
\text { Index }\end{array}$} & \multicolumn{2}{|c|}{ Spoofing Index } & \multicolumn{2}{|c|}{$\begin{array}{l}\text { False Disclosure } \\
\text { Index }\end{array}$} & \multicolumn{2}{|c|}{$\begin{array}{l}\text { Broker Agency } \\
\text { Index }\end{array}$} & \multicolumn{2}{|c|}{$\begin{array}{l}\text { Investor Protection } \\
\text { Index }\end{array}$} \\
\hline & $>2$ & $<=2$ & $>4$ & $<=4$ & $>2$ & $<=2$ & $>1$ & $<=1$ & $>1$ & $<=1$ & $>1$ & $<=1$ & $>0$ & $<=0$ & $>2.27$ & $<=2.27$ \\
\hline Number of Observations & 445 & 918 & 678 & 685 & 537 & 826 & 198 & 1165 & 384 & 979 & 90 & 1273 & 526 & 837 & 660 & 703 \\
\hline Mean & 1.119 & $\begin{array}{c}0.80 \\
8\end{array}$ & 1.134 & 0.689 & 1.105 & 0.783 & 1.216 & 0.858 & 1.331 & 0.745 & 1.614 & 0.860 & 0.864 & 0.939 & 0.896 & 0.923 \\
\hline Standard Deviation & 0.722 & $\begin{array}{c}0.55 \\
7\end{array}$ & 0.636 & 0.545 & 0.598 & 0.622 & 0.501 & 0.638 & 0.557 & 0.582 & 0.660 & 0.600 & 0.661 & 0.612 & 0.607 & 0.655 \\
\hline Median & 1.354 & $\begin{array}{c}0.64 \\
8\end{array}$ & 1.019 & 0.495 & 0.930 & 0.530 & 1.124 & 0.612 & 1.365 & 0.552 & 1.623 & 0.668 & 0.678 & 0.739 & 0.754 & 0.664 \\
\hline $\begin{array}{l}\text { Difference in Means } \\
\text { Difference in Medians }\end{array}$ & \multicolumn{2}{|c|}{$\begin{array}{c}8.01 * * * \\
\mathrm{p}<0.00^{* * * *}\end{array}$} & \multicolumn{2}{|c|}{$\begin{array}{l}13.86^{* * * *} \\
\mathrm{p}<0.00^{* * *}\end{array}$} & \multicolumn{2}{|c|}{$\begin{array}{c}9.50^{* * *} \\
\mathrm{p}<0.00^{* * *}\end{array}$} & \multicolumn{2}{|c|}{$\begin{array}{c}8.90^{* * *} \\
\mathrm{p}<0.00^{* * *}\end{array}$} & \multicolumn{2}{|c|}{$\begin{array}{l}16.93 * * * \\
p<0.00^{* * *}\end{array}$} & \multicolumn{2}{|c|}{$\begin{array}{l}11.44 * * * \\
\mathrm{p}<0.00^{* * * *}\end{array}$} & \multicolumn{2}{|c|}{$\begin{array}{c}-2.11 * * \\
\mathrm{p}<0.00^{* * *}\end{array}$} & \multicolumn{2}{|c|}{$\begin{array}{c}-0.76 \\
p=0.93\end{array}$} \\
\hline \multirow[t]{2}{*}{ Part 2. Subset of MiFID Exchanges } & \multicolumn{2}{|c|}{$\begin{array}{c}\text { Insider } \\
\text { Trading Index }\end{array}$} & \multicolumn{2}{|c|}{$\begin{array}{l}\text { Market Manipulation } \\
\text { Index }\end{array}$} & \multicolumn{2}{|c|}{ Price Manipulation Index } & \multicolumn{2}{|c|}{$\begin{array}{l}\text { Volume } \\
\text { Manipulation } \\
\text { Index }\end{array}$} & \multicolumn{2}{|c|}{ Spoofing Index } & \multicolumn{2}{|c|}{$\begin{array}{l}\text { False Disclosure } \\
\text { Index }\end{array}$} & \multicolumn{2}{|c|}{$\begin{array}{l}\text { Broker Agency } \\
\text { Index }\end{array}$} & \multicolumn{2}{|c|}{$\begin{array}{l}\text { Investor Protection } \\
\text { Index }\end{array}$} \\
\hline & $>2$ & $<=2$ & $>4$ & $<=4$ & $>2$ & $<=2$ & $>1$ & $<=1$ & $>1$ & $<=1$ & $>1$ & $<=1$ & $>0$ & $<=0$ & $>2.27$ & $<=2.27$ \\
\hline Number of Observations & 171 & 225 & 249 & 147 & 207 & 189 & 33 & 363 & 186 & 210 & 24 & 372 & 87 & 309 & 132 & 264 \\
\hline Mean & 1.425 & $\begin{array}{c}1.00 \\
2\end{array}$ & 1.169 & 1.209 & 1.173 & 1.197 & 1.498 & 1.156 & 1.299 & 1.083 & 0.770 & 1.211 & 1.366 & 1.133 & 1.354 & 1.100 \\
\hline Standard Deviation & 0.494 & $\begin{array}{c}0.53 \\
1\end{array}$ & 0.548 & 0.569 & 0.593 & 0.513 & 0.148 & 0.570 & 0.518 & 0.570 & 0.630 & 0.541 & 0.317 & 0.597 & 0.405 & 0.601 \\
\hline Median & 1.449 & $\begin{array}{c}0.86 \\
9\end{array}$ & 1.319 & 1.448 & 1.323 & 1.354 & 1.532 & 1.313 & 1.365 & 1.182 & 0.752 & 1.336 & 1.352 & 1.292 & 1.457 & 1.210 \\
\hline $\begin{array}{l}\text { Difference in Means } \\
\text { Difference in Medians }\end{array}$ & \multicolumn{2}{|c|}{$\begin{array}{c}8.09 * * * \\
\mathrm{p}<0.00 * * *\end{array}$} & \multicolumn{2}{|c|}{$\begin{array}{c}-0.57 \\
\mathrm{p}=0.98\end{array}$} & \multicolumn{2}{|c|}{$\begin{array}{c}-0.57 \\
p=0.98\end{array}$} & \multicolumn{2}{|c|}{$\begin{array}{c}8.68 * * * \\
\mathrm{p}<0.00^{* * * *}\end{array}$} & $\begin{array}{r}3.9 \\
\mathrm{p}<0\end{array}$ & & $\begin{array}{l}-3.8 \\
\mathrm{p}<0 .\end{array}$ & $3^{* * * *}$ & $\begin{array}{r}4.8 \\
\mathrm{p}=0 .\end{array}$ & $02 * *$ & $\begin{array}{r}5.8 \\
\mathrm{p}<0\end{array}$ & $\begin{array}{l}4 * * * \\
00^{* * * *}\end{array}$ \\
\hline & Non-1 & MiFID & Countries & MiFI & Countries & & & & & & & & & & & \\
\hline MiFID & $\begin{array}{r}\text { Post- } \\
\text { MiFID }\end{array}$ & & Pre-MiFID & $\begin{array}{l}\text { Post- } \\
\text { MiFID }\end{array}$ & Pre-MiFID & & & & & & & & & & & \\
\hline Number of Observations & 358 & & 609 & 144 & 252 & & & & & & & & & & & \\
\hline Mean & 0.827 & & 0.780 & 1.267 & 1.137 & & & & & & & & & & & \\
\hline Standard Deviation & 0.644 & & 0.618 & 0.58 & 0.537 & & & & & & & & & & & \\
\hline Median & 0.679 & & 0.563 & 1.373 & 1.276 & & & & & & & & & & & \\
\hline Difference in Means & & 1.1 & 13 & & $* *$ & & & & & & & & & & & \\
\hline Difference in Medians & & $\mathrm{p}=0.3$ & 329 & & $016 * *$ & & & & & & & & & & & \\
\hline
\end{tabular}




\begin{tabular}{|c|c|c|c|c|c|c|c|c|c|c|c|c|c|c|c|c|}
\hline \multirow[t]{2}{*}{$\underline{\text { Part 1. All Countries }}$} & \multicolumn{2}{|c|}{$\begin{array}{l}\text { Insider Trading } \\
\text { Index }\end{array}$} & \multicolumn{2}{|c|}{$\begin{array}{c}\text { Market } \\
\text { Manipulation Index }\end{array}$} & \multicolumn{2}{|c|}{$\begin{array}{l}\text { Price Manipulation } \\
\text { Index }\end{array}$} & \multicolumn{2}{|c|}{$\begin{array}{c}\text { Volume } \\
\text { Manipulation Index }\end{array}$} & \multicolumn{2}{|c|}{ Spoofing Index } & \multicolumn{2}{|c|}{$\begin{array}{l}\text { False Disclosure } \\
\text { Index }\end{array}$} & \multicolumn{2}{|c|}{$\begin{array}{l}\text { Broker Agency } \\
\text { Index }\end{array}$} & \multicolumn{2}{|c|}{$\begin{array}{l}\text { Investor Protection } \\
\text { Index }\end{array}$} \\
\hline & $>2$ & $<=2$ & $>4$ & $<=4$ & $>2$ & $<=2$ & $>1$ & $<=1$ & $>1$ & $<=1$ & $>1$ & $<=1$ & $>0$ & $<=0$ & $>2.27$ & $<=2.27$ \\
\hline Number of Observations & 456 & 863 & 633 & 686 & 525 & 794 & 198 & 1121 & 372 & 947 & 90 & 1229 & 515 & 804 & 659 & 660 \\
\hline Mean & 0.302 & 0.328 & 0.300 & 0.337 & 0.281 & 0.344 & 0.296 & 0.323 & 0.275 & 0.336 & 0.240 & 0.325 & 0.318 & 0.319 & 0.283 & 0.355 \\
\hline Standard Deviation & 0.078 & 0.084 & 0.080 & 0.082 & 0.063 & 0.085 & 0.076 & 0.084 & 0.065 & 0.083 & 0.016 & 0.083 & 0.082 & 0.084 & 0.062 & 0.086 \\
\hline Median & 0.282 & 0.296 & 0.271 & 0.338 & 0.260 & 0.342 & 0.259 & 0.301 & 0.250 & 0.331 & 0.239 & 0.307 & 0.321 & 0.293 & 0.261 & 0.366 \\
\hline $\begin{array}{c}\text { Difference in Means } \\
\text { Difference in Medians }\end{array}$ & \multicolumn{2}{|c|}{$\begin{array}{r}-5.38 * * * \\
\mathrm{p}<0.00^{* * * *} \\
\end{array}$} & \multicolumn{2}{|c|}{$\begin{array}{c}-8.35^{* * * *} \\
\mathrm{p}<0.00 * * *\end{array}$} & \multicolumn{2}{|c|}{$\begin{array}{l}-15.49 * * * \\
\mathrm{p}<0.00 * * *\end{array}$} & \multicolumn{2}{|c|}{$\begin{array}{c}-4.26 * * * \\
\mathrm{p}<0.00 * * * \\
\end{array}$} & \multicolumn{2}{|c|}{$\begin{array}{l}-14.08 * * * \\
\mathrm{p}<0.00 * * *\end{array}$} & \multicolumn{2}{|c|}{$\begin{array}{l}-29.59 * * * \\
\mathrm{p}<0.00 * * *\end{array}$} & \multicolumn{2}{|c|}{$\begin{array}{c}-0.23 \\
\mathrm{p}<0.00^{* * * *} \\
\end{array}$} & \multicolumn{2}{|c|}{$\begin{array}{c}-17.45^{* * * *} \\
\mathrm{p}=0.28\end{array}$} \\
\hline \multirow[t]{2}{*}{ Part 2. Subset of MiFID Exchanges } & \multicolumn{2}{|c|}{$\begin{array}{l}\text { Insider Trading } \\
\text { Index }\end{array}$} & \multicolumn{2}{|c|}{$\begin{array}{c}\text { Market } \\
\text { Manipulation Index }\end{array}$} & \multicolumn{2}{|c|}{$\begin{array}{l}\text { Price Manipulation } \\
\text { Index }\end{array}$} & \multicolumn{2}{|c|}{$\begin{array}{c}\text { Volume } \\
\text { Manipulation Index }\end{array}$} & \multicolumn{2}{|c|}{ Spoofing Index } & \multicolumn{2}{|c|}{$\begin{array}{l}\text { False Disclosure } \\
\text { Index }\end{array}$} & \multicolumn{2}{|c|}{$\begin{array}{l}\text { Broker Agency } \\
\text { Index }\end{array}$} & \multicolumn{2}{|c|}{$\begin{array}{l}\text { Investor Protection } \\
\text { Index }\end{array}$} \\
\hline & $>2$ & $<=2$ & $>4$ & $<=4$ & $>2$ & $<=2$ & $>1$ & $<=1$ & $>1$ & $<=1$ & $>1$ & $<=1$ & $>0$ & $<=0$ & $>2.27$ & $<=2.27$ \\
\hline Number of Observations & 159 & 204 & 237 & 126 & 195 & 168 & 33 & 330 & 174 & 189 & 24 & 339 & 87 & 276 & 132 & 231 \\
\hline Mean & 0.286 & 0.284 & 0.272 & 0.309 & 0.256 & 0.318 & 0.226 & 0.291 & 0.277 & 0.292 & 0.241 & 0.288 & 0.319 & 0.274 & 0.296 & 0.278 \\
\hline Standard Deviation & 0.076 & 0.055 & 0.065 & 0.058 & 0.047 & 0.066 & 0.013 & 0.065 & 0.072 & 0.057 & 0.015 & 0.066 & 0.074 & 0.058 & 0.070 & 0.061 \\
\hline Median & 0.261 & 0.273 & 0.256 & 0.284 & 0.240 & 0.287 & 0.226 & 0.276 & 0.247 & 0.276 & 0.240 & 0.274 & 0.296 & 0.258 & 0.288 & 0.271 \\
\hline $\begin{array}{c}\text { Difference in Means } \\
\text { Difference in Medians }\end{array}$ & \multicolumn{2}{|c|}{$\begin{array}{c}0.30 \\
p=0.26\end{array}$} & \multicolumn{2}{|c|}{$\begin{array}{l}-10.91 * * * \\
\mathrm{p}<0.00 * * *\end{array}$} & \multicolumn{2}{|c|}{$\begin{array}{l}-10.91 * * * \\
\mathrm{p}<0.00 * * *\end{array}$} & \multicolumn{2}{|c|}{$\begin{array}{l}-15.31 * * * \\
\mathrm{p}<0.00 * * *\end{array}$} & \multicolumn{2}{|c|}{$\begin{array}{c}-2.28 * * \\
\mathrm{p}<0.00 * * * \\
\end{array}$} & $\begin{array}{l}-9.9 \\
\mathrm{p}<0 .\end{array}$ & $\begin{array}{l}* * * \\
0 * * * \\
\end{array}$ & $\begin{array}{r}5.1 \\
\mathrm{p}<0 .\end{array}$ & $\begin{array}{l}* * * \\
0 * * * \\
\end{array}$ & $\begin{array}{r}7 \\
\mathrm{p}< \\
\end{array}$ & $2 * * *$ \\
\hline$\frac{\text { Part 3. Pre-MiFID versus Post- }}{\underline{\text { MiFID }}}$ & & Non-MiF & ID Countr & MiFID & Pos & -MiFID & IiFID Cour & Pre-MiFID & & & & & & & & \\
\hline Number of Observations & & 48 & & 08 & & 132 & & 231 & & & & & & & & \\
\hline Mean & & 337 & & 329 & & 261 & & 0.298 & & & & & & & & \\
\hline Standard Deviation & & 092 & & 082 & & .051 & & 0.068 & & & & & & & & \\
\hline Median & & 32 & & 32 & & 245 & & 0.276 & & & & & & & & \\
\hline $\begin{array}{l}\text { Difference in Means } \\
\text { Difference in Medians }\end{array}$ & & & $\begin{array}{l}1.24 \\
=0.446\end{array}$ & & & & $\begin{array}{r}-5.98 * * * \\
\mathrm{p}<=0.000\end{array}$ & & & & & & & & & \\
\hline
\end{tabular}




\begin{tabular}{|c|c|c|c|c|c|c|c|c|c|c|c|c|c|c|c|c|}
\hline \multirow[t]{2}{*}{$\underline{\text { Part 1. All Countries }}$} & \multicolumn{2}{|c|}{$\begin{array}{l}\text { Insider Trading } \\
\text { Index }\end{array}$} & \multicolumn{2}{|c|}{$\begin{array}{c}\text { Market } \\
\text { Manipulation Index }\end{array}$} & \multicolumn{2}{|c|}{$\begin{array}{l}\text { Price Manipulation } \\
\text { Index }\end{array}$} & \multicolumn{2}{|c|}{$\begin{array}{c}\text { Volume } \\
\text { Manipulation Index }\end{array}$} & \multicolumn{2}{|c|}{ Spoofing Index } & \multicolumn{2}{|c|}{$\begin{array}{l}\text { False Disclosure } \\
\text { Index }\end{array}$} & \multicolumn{2}{|c|}{$\begin{array}{l}\text { Broker Agency } \\
\text { Index }\end{array}$} & \multicolumn{2}{|c|}{$\begin{array}{l}\text { Investor Protection } \\
\text { Index }\end{array}$} \\
\hline & $>2$ & $<=2$ & $>4$ & $<=4$ & $>2$ & $<=2$ & $>1$ & $<=1$ & $>1$ & $<=1$ & $>1$ & $<=1$ & $>0$ & $<=0$ & $>2.27$ & $<=2.27$ \\
\hline Number of Observations & 323 & 664 & 459 & 528 & 459 & 528 & 181 & 806 & 343 & 644 & 82 & 905 & 344 & 643 & 475 & 512 \\
\hline Mean & -5.648 & -5.446 & -5.635 & -5.406 & -5.715 & -5.337 & -5.909 & -5.423 & -5.841 & -5.338 & -6.544 & -5.419 & -5.454 & -5.544 & -5.465 & -5.557 \\
\hline Standard Deviation & 1.053 & 1.007 & 0.981 & 1.053 & 1.025 & 0.995 & 0.973 & 1.017 & 0.937 & 1.029 & 0.881 & 0.987 & 1.031 & 1.023 & 1.006 & 1.043 \\
\hline Median & -5.572 & -5.368 & -5.603 & -5.301 & -5.841 & -5.256 & -6.066 & -5.264 & -5.936 & -5.186 & -6.834 & -5.334 & -5.446 & -5.471 & -5.330 & -5.497 \\
\hline $\begin{array}{l}\text { Difference in Means } \\
\text { Difference in Medians }\end{array}$ & \multicolumn{2}{|c|}{$\begin{array}{l}-2.91 * * * \\
\mathrm{p}<0.00 * * *\end{array}$} & \multicolumn{2}{|c|}{$\begin{array}{c}-3.51^{* * *} \\
\mathrm{p}<0.00^{* * *}\end{array}$} & \multicolumn{2}{|c|}{$\begin{array}{c}-5.87 * * * \\
\mathrm{p}<0.00 * * *\end{array}$} & \multicolumn{2}{|c|}{$\begin{array}{c}-5.86 * * * \\
\mathrm{p}<0.00 * * *\end{array}$} & \multicolumn{2}{|c|}{$\begin{array}{l}-7.54 * * * \\
\mathrm{p}<0.00 * * *\end{array}$} & \multicolumn{2}{|c|}{$\begin{array}{c}-9.97 * * * \\
\mathrm{p}<0.00 * * *\end{array}$} & \multicolumn{2}{|c|}{$\begin{array}{c}1.32 \\
\mathrm{p}=0.28\end{array}$} & \multicolumn{2}{|c|}{$\begin{array}{c}1.41 \\
\mathrm{p}=0.14\end{array}$} \\
\hline \multirow{2}{*}{$\frac{\text { Part 2. . Subset of MiFID }}{\underline{\text { Exchanges }}}$} & \multicolumn{2}{|c|}{$\begin{array}{l}\text { Insider Trading } \\
\text { Index }\end{array}$} & \multicolumn{2}{|c|}{$\begin{array}{c}\text { Market } \\
\text { Manipulation Index }\end{array}$} & \multicolumn{2}{|c|}{$\begin{array}{l}\text { Price Manipulation } \\
\text { Index }\end{array}$} & \multicolumn{2}{|c|}{$\begin{array}{c}\text { Volume } \\
\text { Manipulation Index }\end{array}$} & \multicolumn{2}{|c|}{ Spoofing Index } & \multicolumn{2}{|c|}{$\begin{array}{l}\text { False Disclosure } \\
\text { Index }\end{array}$} & \multicolumn{2}{|c|}{$\begin{array}{l}\text { Broker Agency } \\
\text { Index }\end{array}$} & \multicolumn{2}{|c|}{$\begin{array}{l}\text { Investor Protection } \\
\text { Index }\end{array}$} \\
\hline & $>2$ & $<=2$ & $>4$ & $<=4$ & $>2$ & $<=2$ & $>1$ & $<=1$ & $>1$ & $<=1$ & $>1$ & $<=1$ & $>0$ & $<=0$ & $>2.27$ & $<=2.27$ \\
\hline $\begin{array}{c}\text { Number of Observations } \\
\text { Mean }\end{array}$ & $\begin{array}{c}151 \\
-5.858\end{array}$ & $\begin{array}{c}200 \\
-6.026\end{array}$ & $\begin{array}{c}183 \\
-5.808\end{array}$ & $\begin{array}{c}168 \\
-6.113\end{array}$ & $\begin{array}{c}183 \\
-6.008\end{array}$ & $\begin{array}{c}168 \\
-5.895\end{array}$ & $\begin{array}{c}32 \\
-6.699\end{array}$ & $\begin{array}{c}319 \\
-5.879\end{array}$ & $\begin{array}{c}163 \\
-5.934\end{array}$ & $\begin{array}{c}188 \\
-5.972\end{array}$ & $\begin{array}{c}22 \\
-5.884\end{array}$ & $\begin{array}{c}329 \\
-5.959\end{array}$ & $\begin{array}{c}85 \\
-5.924\end{array}$ & $\begin{array}{c}266 \\
-5.964\end{array}$ & $\begin{array}{c}128 \\
-5.748\end{array}$ & $\begin{array}{c}223 \\
-6.072\end{array}$ \\
\hline Standard Deviation & 0.784 & 0.995 & 0.936 & 0.861 & 1.003 & 0.801 & 0.345 & 0.918 & 0.910 & 0.917 & 1.371 & 0.876 & 0.650 & 0.983 & 0.976 & 0.854 \\
\hline Median & -5.547 & -6.372 & -5.603 & -6.483 & -6.380 & -5.683 & -6.679 & -5.685 & -6.055 & -6.311 & -6.060 & -6.207 & -5.600 & -6.368 & -5.771 & -6.276 \\
\hline Difference in Means & \multicolumn{2}{|c|}{$1.77 *$} & \multicolumn{2}{|c|}{$1.67 *$} & \multicolumn{2}{|c|}{$1.67 *$} & \multicolumn{2}{|c|}{$-10.28 * * *$} & & & & & 0. & & & $* * *$ \\
\hline Difference in Medians & $\mathrm{p}=0$. & $2 * * *$ & $\mathrm{p}=0$ & $10^{*}$ & $\mathrm{p}<0.0$ & $0 * * *$ & $\mathrm{p}<0$. & $0 * * *$ & $\mathrm{p}=\mathrm{c}$ & & & & $\mathrm{p}=0$ & & $\mathrm{p}<0$. & $0 * * *$ \\
\hline Part 3. Pre-MiFID versus & $\begin{array}{r}\text { Non-N } \\
\text { Coun }\end{array}$ & & MiFID C & ountries & & & & & & & & & & & & \\
\hline$\underline{\text { Post-MiFID }}$ & $\begin{array}{l}\text { Post- } \\
\text { MiFID }\end{array}$ & $\begin{array}{l}\text { Pre- } \\
\text { MiFID }\end{array}$ & $\begin{array}{l}\text { Post- } \\
\text { MiFID }\end{array}$ & $\begin{array}{l}\text { Pre- } \\
\text { MiFID }\end{array}$ & & & & & & & & & & & & \\
\hline Number of Observations & 234 & 402 & 121 & 230 & & & & & & & & & & & & \\
\hline Mean & -5.119 & -5.356 & -5.927 & -5.969 & & & & & & & & & & & & \\
\hline Standard Deviation & 1.032 & 0.978 & 0.984 & 0.874 & & & & & & & & & & & & \\
\hline Median & -4.972 & -5.037 & -6.066 & -6.281 & & & & & & & & & & & & \\
\hline Difference in Means & 2.89 & **** & 0. & & & & & & & & & & & & & \\
\hline Difference in Medians & $\mathrm{p}=0.00$ & $5 * * *$ & $\mathrm{p}=0$ & 953 & & & & & & & & & & & & \\
\hline
\end{tabular}


Table 5. Correlation Matrix

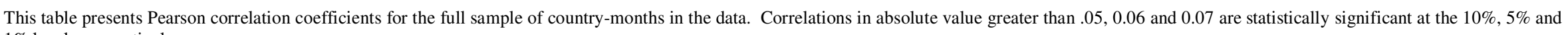
$1 \%$ levels, respectively.

\begin{tabular}{|c|c|c|c|c|c|c|c|c|c|c|c|c|c|c|c|}
\hline & & (1) & (2) & (3) & $(4)$ & $(5)$ & (6) & (7) & $(8)$ & (9) & $(10)$ & $(11)$ & $(12)$ & $(13)$ & $(14)$ \\
\hline (1) & Velocity & 1.00 & & & & & & & & & & & & & \\
\hline (2) & Volatility & -0.04 & 1.00 & & & & & & & & & & & & \\
\hline (3) & Bid-Ask Spread & -0.51 & 0.22 & 1.00 & & & & & & & & & & & \\
\hline (4) & Insider Trading Rules Index & 0.40 & -0.29 & -0.13 & 1.00 & & & & & & & & & & \\
\hline (5) & $\begin{array}{l}\text { Market Manipulation Rules } \\
\text { Index }\end{array}$ & 0.37 & -0.36 & -0.24 & 0.49 & 1.00 & & & & & & & & & \\
\hline (6) & $\begin{array}{l}\text { Price Manipulation Rules } \\
\text { Index }\end{array}$ & 0.29 & -0.36 & -0.19 & 0.35 & 0.96 & 1.00 & & & & & & & & \\
\hline (7) & $\begin{array}{l}\text { Volume Manipulation Rules } \\
\text { Index }\end{array}$ & 0.26 & -0.12 & -0.21 & 0.30 & 0.79 & 0.69 & 1.00 & & & & & & & \\
\hline (8) & Spoofing Rules Index & 0.44 & -0.38 & -0.28 & 0.57 & 0.91 & 0.83 & 0.63 & 1.00 & & & & & & \\
\hline (9) & False Disclosure Rules Index & 0.33 & -0.27 & -0.20 & 0.63 & 0.63 & 0.48 & 0.50 & 0.53 & 1.00 & & & & & \\
\hline (10) & Broker Agency Rules Index & 0.15 & -0.09 & 0.04 & 0.73 & 0.24 & 0.10 & 0.22 & 0.29 & 0.49 & 1.00 & & & & \\
\hline (11) & Surveillance & 0.11 & -0.29 & -0.10 & 0.35 & 0.39 & 0.37 & 0.31 & 0.34 & 0.33 & 0.28 & 1.00 & & & \\
\hline (12) & Efficiency of the Judiciary & 0.15 & -0.53 & -0.24 & 0.33 & 0.37 & 0.35 & 0.23 & 0.43 & 0.21 & 0.29 & 0.18 & 1.00 & & \\
\hline (13) & $\begin{array}{l}\text { Investor Protection Rules } \\
\text { Index }\end{array}$ & 0.04 & -0.28 & -0.13 & 0.34 & 0.24 & 0.15 & 0.33 & 0.27 & 0.18 & 0.45 & 0.13 & 0.44 & 1.00 & \\
\hline (14) & $\log (1+\mathrm{MSCI})$ & -0.01 & -0.01 & -0.10 & -0.04 & -0.13 & -0.15 & -0.03 & -0.12 & -0.05 & 0.00 & -0.01 & -0.02 & 0.01 & 1.00 \\
\hline (15) & $\log (\mathrm{GDP})$ & 0.39 & -0.54 & -0.44 & 0.18 & 0.44 & 0.44 & 0.22 & 0.52 & 0.21 & -0.07 & 0.23 & 0.65 & 0.11 & -0.04 \\
\hline
\end{tabular}


Table 6. Regression Analysis of Market Liquidity

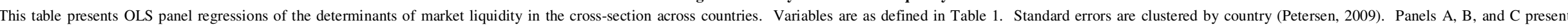

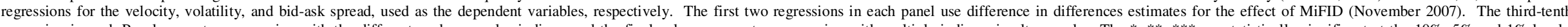

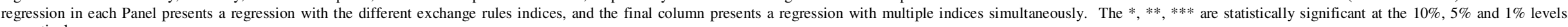
respectively.

\begin{tabular}{|c|c|c|c|c|c|c|c|c|c|c|c|c|c|c|c|c|c|c|c|c|}
\hline & \multicolumn{2}{|c|}{$\begin{array}{c}\text { Model 1: } \\
\text { Difference-in- } \\
\text { Differences }\end{array}$} & \multicolumn{2}{|c|}{$\begin{array}{c}\text { Model 2: } \\
\text { Difference-in- } \\
\text { Differences }\end{array}$} & \multicolumn{2}{|c|}{$\begin{array}{l}\text { Model 3: Insider } \\
\text { Trading Rules Index }\end{array}$} & \multicolumn{2}{|c|}{$\begin{array}{l}\text { Model 4: Market } \\
\text { Manipulation Rules } \\
\text { Index }\end{array}$} & \multicolumn{2}{|c|}{$\begin{array}{l}\text { Model 5: Price } \\
\text { Rules Index }\end{array}$} & \multicolumn{2}{|c|}{$\begin{array}{l}\text { Model 6: Volume } \\
\text { Rules Index }\end{array}$} & \multicolumn{2}{|c|}{$\begin{array}{l}\text { Model 7: Spoofing } \\
\text { Rules Index }\end{array}$} & \multicolumn{2}{|c|}{$\begin{array}{l}\text { Model 8: Disclosure } \\
\text { Rules Index }\end{array}$} & \multicolumn{2}{|c|}{$\begin{array}{c}\text { Models 9: Broker } \\
\text { Agency Rules Index }\end{array}$} & \multicolumn{2}{|c|}{ Models 10: Indices Jointly } \\
\hline & $\begin{array}{c}\text { Coeffi } \\
\text { cient }\end{array}$ & $\begin{array}{c}\mathrm{t}- \\
\text { statisti } \\
\mathrm{c}\end{array}$ & $\begin{array}{c}\text { Coeffici } \\
\text { ent }\end{array}$ & $\begin{array}{c}\mathrm{t}- \\
\text { statistic }\end{array}$ & $\begin{array}{c}\text { Coefficie } \\
\mathrm{nt}\end{array}$ & $\begin{array}{c}\mathrm{t}- \\
\text { statistic }\end{array}$ & $\begin{array}{c}\text { Coeffici } \\
\text { ent }\end{array}$ & t-statistic & $\begin{array}{c}\text { Coeffici } \\
\text { ent }\end{array}$ & $\begin{array}{c}\mathrm{t}- \\
\text { statistic }\end{array}$ & $\begin{array}{c}\text { Coefficie } \\
\mathrm{nt}\end{array}$ & $\begin{array}{c}\mathrm{t}- \\
\text { statisti } \\
\mathrm{c}\end{array}$ & $\begin{array}{c}\text { Coefficie } \\
\text { nt }\end{array}$ & $\begin{array}{c}\mathrm{t}- \\
\text { statisti } \\
\mathrm{c}\end{array}$ & $\begin{array}{c}\text { Coefficie } \\
\text { nt }\end{array}$ & $\begin{array}{c}\mathrm{t}- \\
\text { statisti } \\
\mathrm{c}\end{array}$ & $\begin{array}{c}\text { Coefficie } \\
\mathrm{nt}\end{array}$ & $\begin{array}{c}\mathrm{t}- \\
\text { statisti } \\
\mathrm{c}\end{array}$ & $\begin{array}{c}\text { Coefficie } \\
\mathrm{nt}\end{array}$ & t-statistic \\
\hline Constant & 3.264 & $\stackrel{1.837}{*}$ & -2.360 & $\begin{array}{l}3.106 * \\
* *\end{array}$ & -3.283 & -1.381 & 1.859 & 1.024 & 1.826 & 1.008 & 1.693 & 0.964 & 2.002 & 1.115 & 2.094 & 1.185 & 2.570 & 1.542 & 39.946 & $5.986 * * *$ \\
\hline$\frac{\frac{\text { Difference-in- }}{\text { Differences }}}{\underline{\text { Variables }}}$ & & & & & & & & & & & & & & & & & & & & \\
\hline Treat & -0.115 & $\underset{* * *}{2.867}$ & -4.382 & $5.155^{*}$ & & & & & & & & & & & & & & & & \\
\hline After & 0.019 & 0.858 & 0.055 & $\begin{array}{c}2.719 * \\
* *\end{array}$ & & & & & & & & & & & & & & & & \\
\hline Treat*After & 0.087 & $\begin{array}{c}1.798 \\
*\end{array}$ & 0.047 & $\begin{array}{c}2.475 * \\
*\end{array}$ & & & & & & & & & & & & & & & & \\
\hline$\underline{\text { Trading Rules }}$ & & & & & & & & & & & & & & & & & & & & \\
\hline $\begin{array}{l}\text { Insider Trading } \\
\text { Rules Index } \\
\text { Market } \\
\text { Manipulation }\end{array}$ & & & & & 0.069 & 1.577 & & & & & & & & & & & & & -0.028 & -0.483 \\
\hline $\begin{array}{l}\text { Manipulation } \\
\text { Rules Index }\end{array}$ & & & & & & & 0.013 & $1.847 *$ & & & & & & & & & & & & \\
\hline $\begin{array}{l}\text { Price Rules } \\
\text { Index }\end{array}$ & & & & & & & & & 0.021 & $1.925 *$ & & & & & & & & & 0.002 & 0.221 \\
\hline $\begin{array}{l}\text { Volume Rules } \\
\text { Index }\end{array}$ & & & & & & & & & & & 0.210 & $\begin{array}{l}4.441 \\
* * *\end{array}$ & & & & & & & 0.236 & $3.074 * * *$ \\
\hline $\begin{array}{l}\text { Spoofing Rules } \\
\text { Index }\end{array}$ & & & & & & & & & & & & & 0.042 & 1.137 & & & & & & \\
\hline $\begin{array}{l}\text { Disclosure Rules } \\
\text { Index }\end{array}$ & & & & & & & & & & & & & & & 0.047 & 0.616 & & & & \\
\hline $\begin{array}{l}\text { Broker Agency } \\
\text { Rules Index }\end{array}$ & & & & & & & & & & & & & & & & & -0.226 & $\underset{* * *}{6.917}$ & & \\
\hline Enforcement & & & & & & & & & & & & & & & & & & & & \\
\hline Surveillance & & & 0.012 & $\begin{array}{l}2.315^{*} \\
*\end{array}$ & 0.015 & 1.019 & 0.058 & $5.069 * * *$ & 0.057 & $\underset{* *}{5.003 *}$ & 0.056 & $\begin{array}{l}5.061 \\
{ }_{* * * *}\end{array}$ & 0.059 & $\begin{array}{l}4.986 \\
* * * *\end{array}$ & 0.059 & $\begin{array}{l}4.757 \\
* * * *\end{array}$ & 0.017 & 1.230 & 0.046 & $5.775^{* * *}$ \\
\hline $\begin{array}{l}\text { Efficiency of the } \\
\text { Judiciary } \\
\text { Investor }\end{array}$ & & & 0.650 & $\begin{array}{l}3.697 * \\
* *\end{array}$ & -0.300 & -0.695 & 0.154 & $2.133 * *$ & 0.156 & $\begin{array}{c}2.177^{*} \\
*\end{array}$ & 0.124 & $\begin{array}{c}1.704 \\
*\end{array}$ & 0.161 & $\begin{array}{l}2.254 \\
* *\end{array}$ & 0.172 & $\begin{array}{l}2.560 \\
* *\end{array}$ & 0.202 & $\begin{array}{l}3.325 \\
* * *\end{array}$ & 0.266 & $2.490 * *$ \\
\hline Protection & & & & & & & & & & & & & & & & & & & -5.416 & $-7.150^{* * * *}$ \\
\hline
\end{tabular}




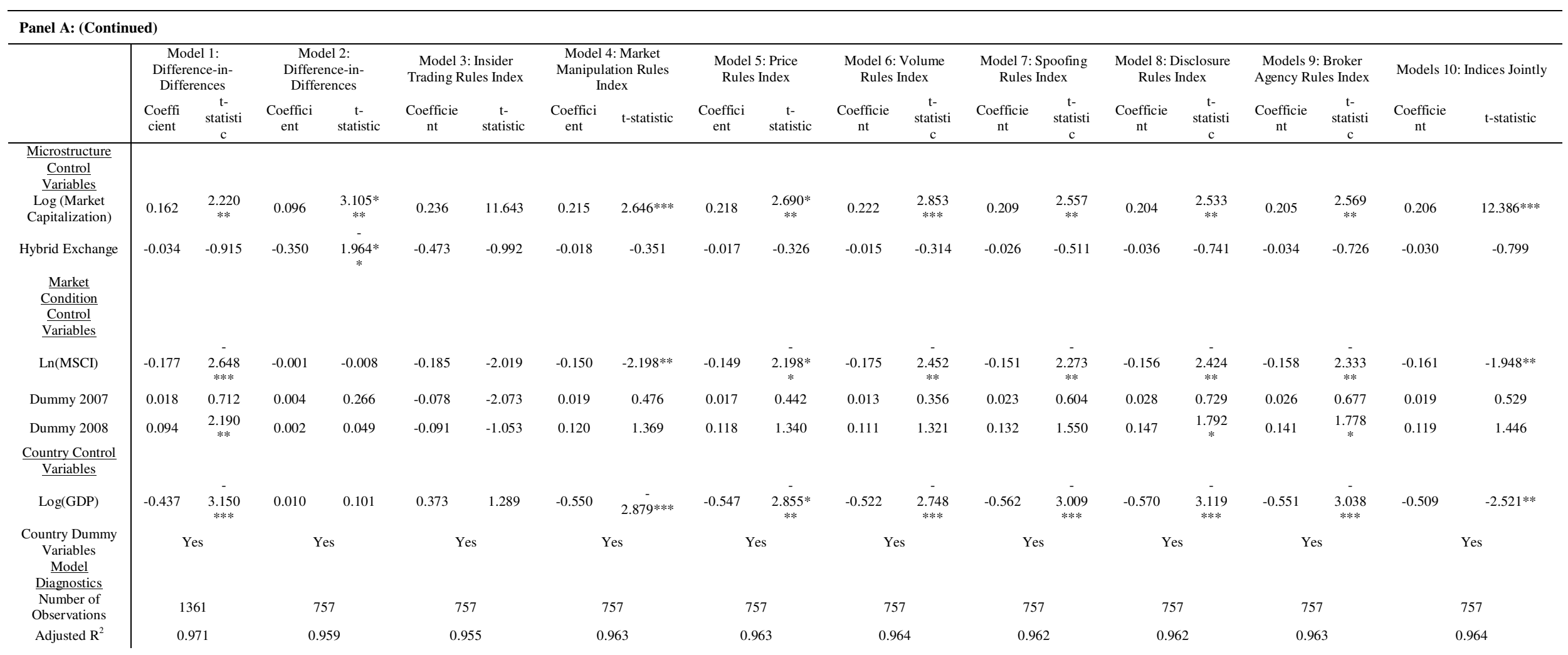




\begin{tabular}{|c|c|c|c|c|c|c|c|c|c|c|c|c|c|c|c|c|c|c|c|c|}
\hline \multicolumn{21}{|l|}{ Panel B: Volatility } \\
\hline & \multicolumn{2}{|c|}{$\begin{array}{l}\text { Model 11: } \\
\text { Difference-in- } \\
\text { Differences }\end{array}$} & \multicolumn{2}{|c|}{$\begin{array}{c}\text { Model 12: } \\
\text { Difference-in- } \\
\text { Differences }\end{array}$} & \multicolumn{2}{|c|}{$\begin{array}{l}\text { Model 13: Insider } \\
\text { Trading Rules Index }\end{array}$} & \multicolumn{2}{|c|}{$\begin{array}{l}\text { Model 14: Market } \\
\text { Manipulation } \\
\text { Rules Index }\end{array}$} & \multicolumn{2}{|c|}{$\begin{array}{l}\text { Model 15: Price } \\
\text { Rules Index }\end{array}$} & \multicolumn{2}{|c|}{$\begin{array}{l}\text { Model 16: } \\
\text { Volume Rules } \\
\text { Index }\end{array}$} & \multicolumn{2}{|c|}{$\begin{array}{l}\text { Model 17: Spoofing } \\
\text { Rules Index }\end{array}$} & \multicolumn{2}{|c|}{$\begin{array}{c}\text { Model 18: } \\
\text { Disclosure Rules } \\
\text { Index }\end{array}$} & \multicolumn{2}{|c|}{$\begin{array}{l}\text { Models 19: Broker } \\
\text { Agency Rules } \\
\text { Index }\end{array}$} & \multicolumn{2}{|c|}{$\begin{array}{l}\text { Models 20: } \\
\text { Indices Jointly }\end{array}$} \\
\hline & $\begin{array}{l}\text { Coeffici } \\
\text { ent }\end{array}$ & $\begin{array}{l}\mathrm{t}- \\
\text { statist } \\
\text { ic } \\
\end{array}$ & $\begin{array}{l}\text { Coeffici } \\
\text { ent }\end{array}$ & $\begin{array}{l}\mathrm{t}- \\
\text { statist } \\
\text { ic } \\
\end{array}$ & $\begin{array}{l}\text { Coeffici } \\
\text { ent }\end{array}$ & $\begin{array}{c}\mathrm{t}- \\
\text { statistic }\end{array}$ & $\begin{array}{l}\text { Coeffici } \\
\text { ent }\end{array}$ & $\begin{array}{c}\mathrm{t}- \\
\text { statist } \\
\text { ic } \\
\end{array}$ & $\begin{array}{l}\text { Coeffici } \\
\text { ent }\end{array}$ & $\begin{array}{c}\mathrm{t}- \\
\text { statist } \\
\text { ic }\end{array}$ & $\begin{array}{c}\text { Coeffici } \\
\text { ent }\end{array}$ & $\begin{array}{c}\mathrm{t}- \\
\text { statist } \\
\text { ic }\end{array}$ & $\begin{array}{l}\text { Coeffici } \\
\text { ent }\end{array}$ & $\begin{array}{c}\mathrm{t}- \\
\text { statistic }\end{array}$ & $\begin{array}{c}\text { Coeffici } \\
\text { ent }\end{array}$ & $\begin{array}{c}\mathrm{t}- \\
\text { statist } \\
\text { ic }\end{array}$ & $\begin{array}{l}\text { Coeffici } \\
\text { ent }\end{array}$ & $\begin{array}{l}\mathrm{t}- \\
\text { statist } \\
\text { ic }\end{array}$ & $\begin{array}{c}\text { Coeffici } \\
\text { ent }\end{array}$ & $\begin{array}{l}\mathrm{t}- \\
\text { statist } \\
\text { ic } \\
\end{array}$ \\
\hline & -0.026 & -0.082 & -0.716 & $\underset{* * *}{2.692}$ & -0.622 & -1.571 & -0.589 & -1.505 & -0.590 & -1.484 & -0.692 & $\begin{array}{c}1.751 \\
*\end{array}$ & -0.651 & $-1.692^{*}$ & -0.624 & -1.593 & -1.070 & $\underset{*}{1.855}$ & -0.566 & -0.163 \\
\hline$\frac{\frac{\text { Difference-in- }}{\text { Differences }}}{\underline{\text { Variables }}}$ & & & & & & & & & & & & & & & & & & & & \\
\hline Treat & 0.048 & $\underset{* * *}{2.593}$ & -0.110 & -0.158 & & & & & & & & & & & & & & & & \\
\hline After & -0.006 & -0.832 & -0.016 & -1.400 & & & & & & & & & & & & & & & & \\
\hline Treat*After & -0.041 & $\begin{array}{c}3.113 \\
* * *\end{array}$ & -0.038 & $\stackrel{-}{2.155}$ & & & & & & & & & & & & & & & & \\
\hline Trading Rules & & & & & & & & & & & & & & & & & & & & \\
\hline $\begin{array}{l}\text { Insider Trading } \\
\text { Rules Index } \\
\text { Market }\end{array}$ & & & & & -0.028 & $2.874^{* * * *}$ & & & & & & & & & & & & & 0.010 & 0.842 \\
\hline $\begin{array}{l}\text { Manipulation Rules } \\
\text { Index }\end{array}$ & & & & & & & -0.006 & $\begin{array}{l}3.708 \\
* * * *\end{array}$ & & & & & & & & & & & & \\
\hline Price Rules Index & & & & & & & & & -0.010 & $\begin{array}{l}3.333 \\
* * * *\end{array}$ & & & & & & & & & -0.015 & $\underset{* *}{2.238}$ \\
\hline $\begin{array}{l}\text { Volume Rules } \\
\text { Index }\end{array}$ & & & & & & & & & & & -0.043 & $\begin{array}{l}3.350 \\
* * *\end{array}$ & & & & & & & 0.024 & 0.585 \\
\hline $\begin{array}{l}\text { Spoofing Rules } \\
\text { Index }\end{array}$ & & & & & & & & & & & & & -0.021 & $\stackrel{-}{-} .815^{* * *}$ & & & & & & \\
\hline $\begin{array}{l}\text { Disclosure Rules } \\
\text { Index }\end{array}$ & & & & & & & & & & & & & & & -0.027 & $\begin{array}{l}1.748 \\
*\end{array}$ & & & & \\
\hline $\begin{array}{l}\text { Broker Agency } \\
\text { Rules Index } \\
\text { Enforcement }\end{array}$ & & & & & & & & & & & & & & & & & 0.039 & 1.440 & & \\
\hline Surveillance & & & 0.004 & 0.869 & $\begin{array}{l}9.042 \mathrm{E}- \\
04\end{array}$ & 0.325 & 0.003 & 1.128 & 0.003 & 1.194 & 0.003 & 1.107 & 0.003 & 0.974 & 0.003 & 1.226 & 0.007 & $\begin{array}{c}1.757 \\
*\end{array}$ & 0.004 & 1.040 \\
\hline $\begin{array}{l}\text { Efficiency of the } \\
\text { Judiciary }\end{array}$ & & & -0.010 & -0.066 & -0.013 & -1.400 & -0.021 & $\begin{array}{l}3.267 \\
* * *\end{array}$ & -0.024 & $\begin{array}{l}3.802 \\
* * * *\end{array}$ & -0.027 & $\begin{array}{l}5.042 \\
* * *\end{array}$ & -0.024 & $\begin{array}{l}- \\
3.559 * * *\end{array}$ & -0.023 & $\underset{* *}{2.343}$ & -0.062 & $\underset{* * *}{2.773}$ & -0.031 & -0.688 \\
\hline $\begin{array}{l}\text { Investor Protection } \\
\text { Index }\end{array}$ & & & & & & & & & & & & & & & & & & & -0.004 & -0.010 \\
\hline
\end{tabular}




\begin{tabular}{|c|c|c|c|c|c|c|c|c|c|c|c|c|c|c|c|c|c|c|c|c|}
\hline \multicolumn{21}{|c|}{ Panel B: Volatility (Continued) } \\
\hline & \multicolumn{2}{|c|}{$\begin{array}{c}\text { Model 11: } \\
\text { Difference-in- } \\
\text { Differences }\end{array}$} & \multicolumn{2}{|c|}{$\begin{array}{c}\text { Model 12: } \\
\text { Difference-in- } \\
\text { Differences }\end{array}$} & \multicolumn{2}{|c|}{$\begin{array}{l}\text { Model 13: Insider } \\
\text { Trading Rules Index }\end{array}$} & \multicolumn{2}{|c|}{$\begin{array}{l}\text { Model 14: Market } \\
\text { Manipulation } \\
\text { Rules Index }\end{array}$} & \multicolumn{2}{|c|}{$\begin{array}{l}\text { Model 15: Price } \\
\text { Rules Index }\end{array}$} & \multicolumn{2}{|c|}{$\begin{array}{l}\text { Model 16: } \\
\text { Volume Rules } \\
\text { Index }\end{array}$} & \multicolumn{2}{|c|}{$\begin{array}{l}\text { Model 17: Spoofing } \\
\text { Rules Index }\end{array}$} & \multicolumn{2}{|c|}{$\begin{array}{c}\text { Model 18: } \\
\text { Disclosure Rules } \\
\text { Index }\end{array}$} & \multicolumn{2}{|c|}{$\begin{array}{l}\text { Models 19: Broker } \\
\text { Agency Rules } \\
\text { Index }\end{array}$} & \multicolumn{2}{|c|}{$\begin{array}{l}\text { Models 20: } \\
\text { Indices Jointly }\end{array}$} \\
\hline & $\begin{array}{c}\text { Coeffici } \\
\text { ent }\end{array}$ & $\begin{array}{l}\mathrm{t}- \\
\text { statist } \\
\text { ic } \\
\end{array}$ & $\begin{array}{c}\text { Coeffici } \\
\text { ent }\end{array}$ & $\begin{array}{l}\mathrm{t}- \\
\text { statist } \\
\text { ic } \\
\end{array}$ & $\begin{array}{c}\text { Coeffici } \\
\text { ent }\end{array}$ & $\begin{array}{c}\mathrm{t}- \\
\text { statistic }\end{array}$ & $\begin{array}{c}\text { Coeffici } \\
\text { ent }\end{array}$ & $\begin{array}{l}\mathrm{t}- \\
\text { statist } \\
\text { ic } \\
\end{array}$ & $\begin{array}{l}\text { Coeffici } \\
\text { ent }\end{array}$ & $\begin{array}{l}\mathrm{t}- \\
\text { statist } \\
\text { ic }\end{array}$ & $\begin{array}{c}\text { Coeffici } \\
\text { ent }\end{array}$ & $\begin{array}{l}\mathrm{t}- \\
\text { statist } \\
\text { ic }\end{array}$ & $\begin{array}{c}\text { Coeffici } \\
\text { ent }\end{array}$ & $\begin{array}{c}\mathrm{t}- \\
\text { statistic }\end{array}$ & $\begin{array}{c}\text { Coeffici } \\
\text { ent }\end{array}$ & $\begin{array}{l}\mathrm{t}- \\
\text { statist } \\
\text { ic }\end{array}$ & $\begin{array}{c}\text { Coeffici } \\
\text { ent }\end{array}$ & $\begin{array}{l}\mathrm{t}- \\
\text { statist } \\
\text { ic }\end{array}$ & $\begin{array}{c}\text { Coeffici } \\
\text { ent }\end{array}$ & $\begin{array}{l}\mathrm{t}- \\
\text { statist } \\
\text { ic }\end{array}$ \\
\hline \multicolumn{21}{|l|}{$\frac{\text { Microstructure }}{\text { Control Variables }}$} \\
\hline $\begin{array}{c}\text { Log (Market } \\
\text { Capitalization) }\end{array}$ & 0.034 & $\begin{array}{c}1.857 \\
*\end{array}$ & 0.064 & $\begin{array}{l}3.139 \\
* * * *\end{array}$ & 0.061 & $2.897 * * *$ & 0.061 & $\begin{array}{l}3.003 \\
* * *\end{array}$ & 0.060 & $\begin{array}{c}2.880 \\
* * * *\end{array}$ & 0.063 & $\begin{array}{l}2.935 \\
* * *\end{array}$ & 0.064 & $3.198^{* * *}$ & 0.067 & $\begin{array}{l}3.319 \\
* * *\end{array}$ & 0.065 & $\begin{array}{l}3.255 \\
* * *\end{array}$ & 0.061 & $\begin{array}{c}3.082 \\
* * *\end{array}$ \\
\hline Hybrid Exchange & 0.023 & $\begin{array}{l}5.766 \\
* * *\end{array}$ & 0.039 & $\begin{array}{l}5.295 \\
* * *\end{array}$ & 0.038 & 1.014 & 0.039 & 1.041 & 0.035 & 0.919 & 0.037 & 1.016 & 0.041 & 1.109 & 0.053 & 1.555 & 0.019 & 0.474 & 0.037 & $\begin{array}{l}5.417 \\
* * *\end{array}$ \\
\hline \multicolumn{21}{|l|}{$\begin{array}{l}\text { Market Condition } \\
\text { Control Variables }\end{array}$} \\
\hline $\operatorname{Ln}(\mathrm{MSCI})$ & -0.081 & $\begin{array}{l}3.594 \\
* * *\end{array}$ & -0.103 & $\begin{array}{l}4.833 \\
* * *\end{array}$ & -0.089 & ${\stackrel{-}{4.763^{* * * *}}}^{-}$ & -0.093 & 5.246 & -0.094 & $\begin{array}{l}5.257 \\
* * *\end{array}$ & -0.085 & $\begin{array}{l}4.282 \\
* * *\end{array}$ & -0.093 & $5.206^{-6 * * *}$ & -0.092 & $\begin{array}{l}4.740 \\
* * *\end{array}$ & -0.086 & $\underset{* * *}{4.252}$ & -0.098 & $\underset{* .512}{5 * *}$ \\
\hline Dummy 2007 & -0.018 & $\begin{array}{l}3.905 \\
* * *\end{array}$ & -0.033 & $\begin{array}{l}3.994 \\
* * *\end{array}$ & -0.034 & $\stackrel{-}{-} \cdot 977^{* * * *}$ & -0.034 & 6.069 & -0.033 & $\begin{array}{c}6.299 \\
* * *\end{array}$ & -0.036 & $\begin{array}{l}5.388 \\
* * *\end{array}$ & -0.036 & ${\stackrel{-}{-} .975^{* * *}}^{-}$ & -0.037 & $\begin{array}{l}5.134 \\
* * *\end{array}$ & -0.043 & 6.390 & -0.034 & $\begin{array}{c}4.004 \\
* * * *\end{array}$ \\
\hline Dummy 2008 & 0.002 & 0.111 & -0.017 & -0.861 & -0.032 & -3.420 & -0.029 & $\begin{array}{l}3 . \\
3.272 \\
* * *\end{array}$ & -0.028 & $\begin{array}{l}3 . \\
* * 303 \\
* * *\end{array}$ & -0.039 & $\begin{array}{l}3 . \\
3.316 \\
* * *\end{array}$ & -0.034 & $-\overline{-}$ & -0.038 & $\begin{array}{c}-\overline{8} \\
* * * \\
* * *\end{array}$ & -0.055 & $\begin{array}{c}4.313 \\
* * *\end{array}$ & -0.029 & -1.597 \\
\hline$\frac{\text { Country Control }}{\text { Variables }}$ & & & & & & & & & & & & & & & & & & & & \\
\hline $\log (\mathrm{GDP})$ & -0.014 & -0.297 & 0.038 & 0.416 & 0.039 & 1.377 & 0.033 & 1.161 & 0.037 & 1.248 & 0.047 & $\begin{array}{c}1.743 \\
*\end{array}$ & 0.040 & 1.400 & 0.029 & 0.929 & 0.098 & $\begin{array}{c}1.668 \\
*\end{array}$ & 0.037 & 0.398 \\
\hline $\begin{array}{l}\text { Country Dummy } \\
\text { Variables }\end{array}$ & \multicolumn{2}{|c|}{ Yes } & \multicolumn{2}{|c|}{ Yes } & \multicolumn{2}{|c|}{ Yes } & \multicolumn{2}{|c|}{ Yes } & \multirow{2}{*}{\multicolumn{2}{|c|}{ Yes }} & \multicolumn{2}{|c|}{ Yes } & \multirow{2}{*}{\multicolumn{2}{|c|}{ Yes }} & \multicolumn{2}{|c|}{ Yes } & \multicolumn{2}{|c|}{ Yes } & \multicolumn{2}{|c|}{ Yes } \\
\hline \multicolumn{18}{|l|}{ Model Diagnostics } & & & \\
\hline $\begin{array}{l}\text { Number of } \\
\text { Observations }\end{array}$ & \multicolumn{2}{|c|}{1294} & \multirow{2}{*}{\multicolumn{2}{|c|}{$\begin{array}{c}757 \\
0851\end{array}$}} & \multicolumn{2}{|c|}{757} & \multicolumn{2}{|c|}{757} & \multirow{2}{*}{\multicolumn{2}{|c|}{$\begin{array}{c}757 \\
0855\end{array}$}} & \multirow{2}{*}{\multicolumn{2}{|c|}{$\begin{array}{c}757 \\
0842\end{array}$}} & \multirow{2}{*}{\multicolumn{2}{|c|}{757}} & 757 & & 757 & & 757 & \\
\hline Adjusted $\mathrm{R}^{2}$ & 0.8 & & & & & 46 & 0.8 & & & & & & & & 0.83 & & 0.83 & & 0.85 & \\
\hline
\end{tabular}




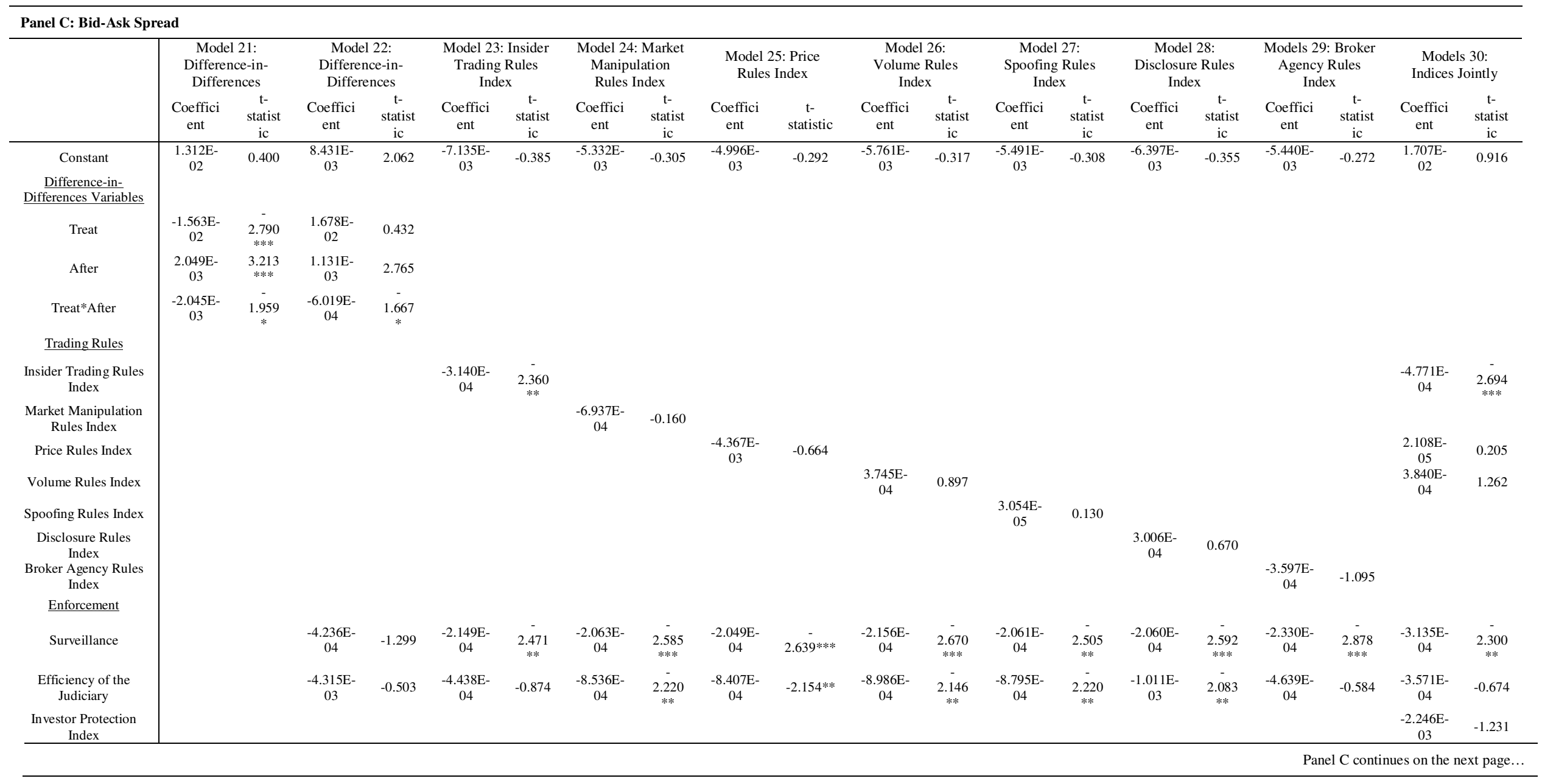




\begin{tabular}{|c|c|c|c|c|c|c|c|c|c|c|c|c|c|c|c|c|c|c|c|c|}
\hline \multicolumn{21}{|c|}{ Panel C: Bid-Ask Spread (Continued) } \\
\hline & \multicolumn{2}{|c|}{$\begin{array}{c}\text { Model 21: } \\
\text { Difference-in- } \\
\text { Differences }\end{array}$} & \multicolumn{2}{|c|}{$\begin{array}{c}\text { Model 22: } \\
\text { Difference-in- } \\
\text { Differences }\end{array}$} & \multicolumn{2}{|c|}{$\begin{array}{l}\text { Model 23: Insider } \\
\text { Trading Rules } \\
\text { Index }\end{array}$} & \multicolumn{2}{|c|}{$\begin{array}{l}\text { Model 24: Market } \\
\text { Manipulation } \\
\text { Rules Index }\end{array}$} & \multicolumn{2}{|c|}{$\begin{array}{l}\text { Model 25: Price } \\
\text { Rules Index }\end{array}$} & \multicolumn{2}{|c|}{$\begin{array}{l}\text { Model 26: } \\
\text { Volume Rules } \\
\text { Index }\end{array}$} & \multicolumn{2}{|c|}{$\begin{array}{l}\text { Model 27: } \\
\text { Spoofing Rules } \\
\text { Index }\end{array}$} & \multicolumn{2}{|c|}{$\begin{array}{c}\text { Model 28: } \\
\text { Disclosure Rules } \\
\text { Index }\end{array}$} & \multicolumn{2}{|c|}{$\begin{array}{l}\text { Models 29: Broker } \\
\text { Agency Rules } \\
\text { Index }\end{array}$} & \multicolumn{2}{|c|}{$\begin{array}{l}\text { Models 30: } \\
\text { Indices Jointly }\end{array}$} \\
\hline & $\begin{array}{c}\text { Coeffici } \\
\text { ent }\end{array}$ & $\begin{array}{c}\mathrm{t}- \\
\text { statist } \\
\text { ic } \\
\end{array}$ & $\begin{array}{c}\text { Coeffici } \\
\text { ent }\end{array}$ & $\begin{array}{c}\mathrm{t}- \\
\text { statist } \\
\text { ic } \\
\end{array}$ & $\begin{array}{c}\text { Coeffici } \\
\text { ent }\end{array}$ & $\begin{array}{l}\mathrm{t}- \\
\text { statist } \\
\text { ic } \\
\end{array}$ & $\begin{array}{l}\text { Coeffici } \\
\text { ent }\end{array}$ & $\begin{array}{c}\mathrm{t}- \\
\text { statist } \\
\text { ic } \\
\end{array}$ & $\begin{array}{c}\text { Coeffici } \\
\text { ent }\end{array}$ & $\begin{array}{c}\mathrm{t}- \\
\text { statistic }\end{array}$ & $\begin{array}{c}\text { Coeffici } \\
\text { ent }\end{array}$ & $\begin{array}{c}\mathrm{t}- \\
\text { statist } \\
\text { ic }\end{array}$ & $\begin{array}{c}\text { Coeffici } \\
\text { ent }\end{array}$ & $\begin{array}{c}\mathrm{t}- \\
\text { statist } \\
\text { ic }\end{array}$ & $\begin{array}{c}\text { Coeffici } \\
\text { ent }\end{array}$ & $\begin{array}{c}\mathrm{t}- \\
\text { statist } \\
\text { ic }\end{array}$ & $\begin{array}{c}\text { Coeffici } \\
\text { ent }\end{array}$ & $\begin{array}{c}\mathrm{t}- \\
\text { statist } \\
\text { ic }\end{array}$ & $\begin{array}{c}\text { Coeffici } \\
\text { ent }\end{array}$ & $\begin{array}{l}\mathrm{t}- \\
\text { statist } \\
\text { ic }\end{array}$ \\
\hline \multicolumn{21}{|l|}{$\begin{array}{c}\text { Microstructure } \\
\text { Control Variables }\end{array}$} \\
\hline $\begin{array}{c}\text { Log (Market } \\
\text { Capitalization) }\end{array}$ & $\begin{array}{c}-3.370 \mathrm{E}- \\
03\end{array}$ & $\underset{* * *}{2.968}$ & $\begin{array}{c}-1.880 \mathrm{E}- \\
03\end{array}$ & $\begin{array}{l}2.567 \\
* *\end{array}$ & $\begin{array}{l}-9.087 \mathrm{E}- \\
04\end{array}$ & $\begin{array}{l}4.097 \\
* * * *\end{array}$ & $\begin{array}{c}-6.628 \mathrm{E}- \\
04\end{array}$ & $\begin{array}{l}2.700 \\
* * *\end{array}$ & $\begin{array}{c}-6.481 \mathrm{E}- \\
04\end{array}$ & $2.661^{* * *}$ & $\begin{array}{l}-7.916 \mathrm{E}- \\
04\end{array}$ & $\begin{array}{l}2.958 \\
* * * *\end{array}$ & $\begin{array}{c}-6.745 \mathrm{E}- \\
04\end{array}$ & $\begin{array}{l}2.920 \\
* * * *\end{array}$ & $\begin{array}{c}-7.016 \mathrm{E}- \\
04\end{array}$ & $\underset{* * * *}{2.933}$ & $\begin{array}{c}-8.262 \mathrm{E}- \\
04\end{array}$ & $\begin{array}{l}3.044 \\
* * * *\end{array}$ & $\begin{array}{c}-1.386 \mathrm{E}- \\
03\end{array}$ & $\begin{array}{c}3.080 \\
* * *\end{array}$ \\
\hline Hybrid Exchange & $\begin{array}{l}-2.281 \mathrm{E}- \\
03\end{array}$ & -0.411 & $\begin{array}{c}5.086 \mathrm{E}- \\
03\end{array}$ & $\begin{array}{l}12.70 \\
2^{* * * *}\end{array}$ & $\begin{array}{l}6.884 \mathrm{E}- \\
03\end{array}$ & $\underset{* *}{2.322}$ & $\begin{array}{l}6.115 \mathrm{E}- \\
03\end{array}$ & $\underset{* *}{2.201}$ & $\begin{array}{l}6.071 \mathrm{E}- \\
03\end{array}$ & $2.245^{* *}$ & $\begin{array}{l}6.339 \mathrm{E}- \\
03\end{array}$ & $\underset{* *}{2.249}$ & $\begin{array}{l}6.113 \mathrm{E}- \\
03\end{array}$ & $\begin{array}{l}2.167 \\
* *\end{array}$ & $\begin{array}{l}5.913 \mathrm{E}- \\
03\end{array}$ & $\underset{* *}{2.201}$ & $\begin{array}{l}7.116 \mathrm{E}- \\
03\end{array}$ & $\underset{* * *}{2.592}$ & $\begin{array}{l}6.677 \mathrm{E}- \\
03\end{array}$ & $\stackrel{2.560}{* *}$ \\
\hline $\begin{array}{l}\log \text { (Number of } \\
\text { Trades) }\end{array}$ & $\begin{array}{c}-3.811 \mathrm{E}- \\
04\end{array}$ & -0.319 & $\begin{array}{c}-3.887 \mathrm{E}- \\
04\end{array}$ & -1.434 & $\begin{array}{c}-1.664 \mathrm{E}- \\
04\end{array}$ & -0.708 & $\begin{array}{l}-4.861 \mathrm{E}- \\
04\end{array}$ & $\stackrel{2.749}{* * *}$ & $\begin{array}{l}-4.975 \mathrm{E}- \\
04\end{array}$ & ${ }^{-} .719^{* * * *}$ & $\begin{array}{l}-4.264 \mathrm{E}- \\
04\end{array}$ & 2.208 & $\begin{array}{l}-4.846 \mathrm{E}- \\
04\end{array}$ & $\underset{* * *}{3.010}$ & $\begin{array}{c}-4.871 \mathrm{E}- \\
04\end{array}$ & $\stackrel{2.969}{* * *}$ & $\begin{array}{l}-2.355 \mathrm{E}- \\
04\end{array}$ & -0.651 & $\begin{array}{l}-4.241 \mathrm{E}- \\
04\end{array}$ & -0.916 \\
\hline Volatility & $\begin{array}{l}5.053 \mathrm{E}- \\
03\end{array}$ & 0.871 & $\begin{array}{l}2.535 \mathrm{E}- \\
03\end{array}$ & 1.157 & $\begin{array}{c}-5.399 \mathrm{E}- \\
04\end{array}$ & -0.185 & $\begin{array}{c}-2.840 \mathrm{E}- \\
04\end{array}$ & -0.077 & $\begin{array}{c}-7.486 \mathrm{E}- \\
04\end{array}$ & -0.205 & $\begin{array}{l}6.157 \mathrm{E}- \\
04\end{array}$ & 0.180 & $\begin{array}{c}.277607 \\
\mathrm{D}-04\end{array}$ & -0.008 & $\begin{array}{l}1.926 \mathrm{E}- \\
04\end{array}$ & 0.061 & $\begin{array}{l}3.791 \mathrm{E}- \\
04\end{array}$ & 0.115 & $\begin{array}{c}1.346 \mathrm{E}- \\
03\end{array}$ & 0.374 \\
\hline \multicolumn{21}{|l|}{$\frac{\text { Market Condition }}{\text { Control Variables }}$} \\
\hline $\mathrm{Ln}(\mathrm{MSCl})$ & $\begin{array}{c}-1.558 \mathrm{E}- \\
03\end{array}$ & -0.519 & $\begin{array}{c}-6.799 \mathrm{E}- \\
04\end{array}$ & -0.444 & $\begin{array}{l}-1.851 \mathrm{E}- \\
03\end{array}$ & -1.069 & $\begin{array}{c}-1.631 \mathrm{E}- \\
03\end{array}$ & -0.926 & $\begin{array}{l}-1.668 \mathrm{E}- \\
03\end{array}$ & -0.940 & $\begin{array}{c}-1.600 \mathrm{E}- \\
03\end{array}$ & -0.906 & $\begin{array}{c}-1.604 \mathrm{E}- \\
03\end{array}$ & -0.925 & $\begin{array}{l}-1.558 \mathrm{E}- \\
03\end{array}$ & -0.900 & $\begin{array}{c}-1.743 \mathrm{E}- \\
03\end{array}$ & -1.003 & $\begin{array}{l}-1.518 \mathrm{E}- \\
03\end{array}$ & -0.900 \\
\hline Dummy 2007 & $\begin{array}{l}2.153 \mathrm{E}- \\
04\end{array}$ & 0.356 & $\begin{array}{l}-3.484 \mathrm{E}- \\
04\end{array}$ & -1.090 & $\begin{array}{c}-3.939 \mathrm{E}- \\
04\end{array}$ & -1.024 & $\begin{array}{l}-5.235 \mathrm{E}- \\
04\end{array}$ & -1.486 & $\begin{array}{l}-5.183 \mathrm{E}- \\
04\end{array}$ & -1.483 & $\begin{array}{c}-4.949 \mathrm{E}- \\
04\end{array}$ & -1.345 & $\begin{array}{c}-5.276 \mathrm{E}- \\
04\end{array}$ & -1.490 & $\begin{array}{c}-5.444 \mathrm{E}- \\
04\end{array}$ & -1.530 & $\begin{array}{c}-4.328 \mathrm{E}- \\
04\end{array}$ & -1.058 & $\begin{array}{l}-2.007 \mathrm{E}- \\
04\end{array}$ & -0.530 \\
\hline Dummy 2008 & $\begin{array}{c}5.614 \mathrm{E}- \\
04\end{array}$ & 0.381 & $\begin{array}{c}-8.999 \mathrm{E}- \\
04\end{array}$ & -0.927 & $\begin{array}{l}5.267 \mathrm{E}- \\
05\end{array}$ & 0.129 & $\begin{array}{l}1.917 \mathrm{E}- \\
05\end{array}$ & 0.050 & $\begin{array}{l}7.385 \mathrm{E}- \\
05\end{array}$ & 0.199 & $\begin{array}{l}-6.547 \mathrm{E}- \\
05\end{array}$ & -0.166 & $\begin{array}{c}-1.636 \mathrm{E}- \\
05\end{array}$ & -0.040 & $\begin{array}{l}-9.407 \mathrm{E}- \\
05\end{array}$ & -0.212 & $\begin{array}{l}-3.553 \mathrm{E}- \\
05\end{array}$ & -0.085 & $\begin{array}{l}3.665 \mathrm{E}- \\
04\end{array}$ & 0.984 \\
\hline Variables & & & & & & & & & & & & & & & & & & & & \\
\hline$\overline{\log (\mathrm{GDP})}$ & $\begin{array}{l}4.559 \mathrm{E}- \\
03\end{array}$ & $\begin{array}{c}1.796 \\
*\end{array}$ & $\begin{array}{l}5.262 \mathrm{E}- \\
03\end{array}$ & 0.938 & $\begin{array}{l}3.227 \mathrm{E}- \\
03\end{array}$ & 1.400 & $\begin{array}{l}3.231 \mathrm{E}- \\
03\end{array}$ & 1.498 & $\begin{array}{l}3.200 \mathrm{E}- \\
03\end{array}$ & 1.507 & $\begin{array}{l}3.374 \mathrm{E}- \\
03\end{array}$ & 1.516 & $\begin{array}{l}3.264 \mathrm{E}- \\
03\end{array}$ & 1.482 & $\begin{array}{l}3.483 \mathrm{E}- \\
03\end{array}$ & 1.515 & $\begin{array}{l}2.961 \mathrm{E}- \\
03\end{array}$ & 1.107 & $\begin{array}{l}3.272 \mathrm{E}- \\
03\end{array}$ & 1.502 \\
\hline $\begin{array}{l}\text { Country Dummy } \\
\text { Variables }\end{array}$ & \multicolumn{2}{|c|}{ Yes } & \multicolumn{2}{|c|}{ Yes } & \multicolumn{2}{|c|}{ Yes } & \multicolumn{2}{|c|}{ Yes } & \multicolumn{2}{|c|}{ Yes } & \multicolumn{2}{|c|}{ Yes } & \multicolumn{2}{|l|}{ Yes } & \multicolumn{2}{|c|}{ Yes } & \multicolumn{2}{|c|}{ Yes } & \multicolumn{2}{|c|}{ Yes } \\
\hline$\underline{\text { Model Diagnostics }}$ & & & & & & & & & & & & & & & & & & & & \\
\hline $\begin{array}{c}\text { Number of } \\
\text { Observations }\end{array}$ & \multicolumn{2}{|c|}{921} & \multicolumn{2}{|c|}{615} & \multicolumn{2}{|c|}{615} & \multicolumn{2}{|c|}{615} & \multirow{2}{*}{\multicolumn{2}{|c|}{615}} & \multicolumn{2}{|c|}{615} & \multicolumn{2}{|c|}{615} & 615 & & 615 & & 61 & \\
\hline Adjusted $\mathrm{R}^{2}$ & 0.72 & & 0.8 & & 0.8 & & 0.8 & & & & 0.8 & & 0.80 & & 0.80 & & 0.80 & & 0.8 & \\
\hline
\end{tabular}

